\title{
Manufacturing Process Development for Belzutifan, Part 3: Completing a Streamlined Through-Process with a Safe and Scalable Oxidation
}

Zhiwei Chen*a, Nastaran Salehi Marzijarani ${ }^{\mathrm{a}}$, Scott Quirie $^{\mathrm{a}}$, Gregory F. Pirrone ${ }^{\mathrm{b}}$, Stephen M. Dalby ${ }^{\mathrm{a}}$, Tao Wanga , Jungchul Kimª, Feng Peng ${ }^{\mathrm{a}}$, Adam J. Fine ${ }^{\mathrm{a}}$

${ }^{a}$ Department of Process Research and Development, Merck \& Co. Inc., Rahway, New Jersey, 07065, United States;

${ }^{b}$ Department of Analytical Research and Development, Merck \& Co. Inc., Rahway, New Jersey, 07065, United States.

Table of Contents

Page

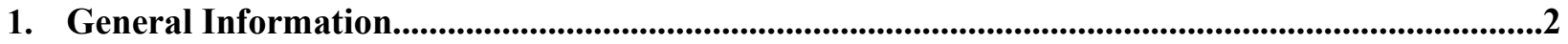

2. Differential scanning calorimetry (DSC) with oxidation pre-reaction mixtures..............................3

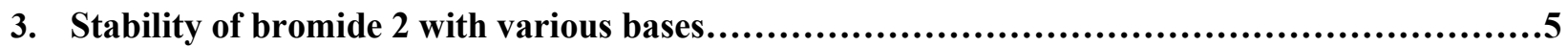

4. Investigation of other potential quench reagents and reverse quench stability...................6

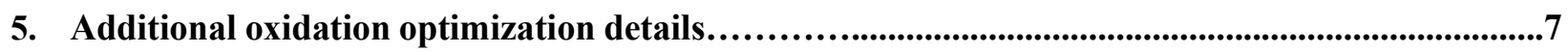

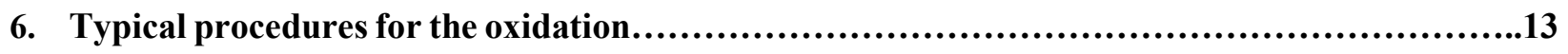

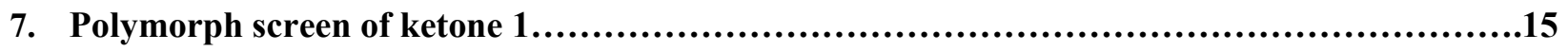

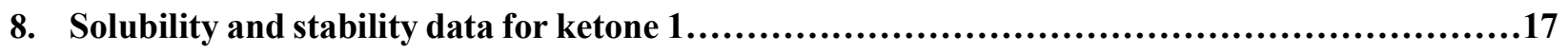

9. HPLC analytical method and chromatograms............................................19

10. NMR data and spectra .................................................................22

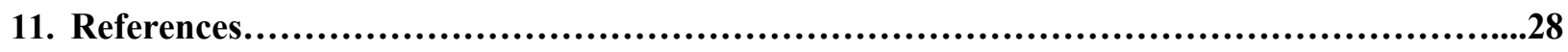




\section{General Information}

Reagents were purchased in reagent grade from commercial suppliers and used without further purification, unless otherwise described. Acetonitrile $(\mathrm{MeCN})$ solvent was ordered from Fisher. Proton nuclear magnetic resonance $\left({ }^{1} \mathrm{H}\right.$ NMR $)$ spectra, carbon nuclear magnetic resonance $\left({ }^{13} \mathrm{C}\right.$ NMR) spectra and proton decoupled fluorine nuclear magnetic resonance $\left({ }^{19} \mathrm{~F} N M R\right)$ were recorded at $25{ }^{\circ} \mathrm{C}$ (unless stated otherwise) on a Bruker DRX-400 spectrometer. Chemical shifts for protons are reported in parts per million downfield from tetramethylsilane and are referenced to residual proton of the NMR solvent according to values reported in the literature. ${ }^{1}$ Chemical shifts for carbon are reported in parts per million downfield from tetramethylsilane and are referenced to the carbon resonances of the NMR solvent. Data are represented as follows: chemical shift, integration, multiplicity $(\mathrm{br}=$ broad, $\mathrm{s}=$ singlet, $\mathrm{d}=$ doublet, $\mathrm{t}=$ triplet, $\mathrm{q}=$ quartet, quint $=$ quintet, $\mathrm{m}=$ multiplet, $\mathrm{dt}=$ doublet of triplets), coupling constants $(J)$ in $\operatorname{Hertz}(\mathrm{Hz})$. 


\section{Differential scanning calorimetry (DSC) with oxidation pre-reaction mixtures}
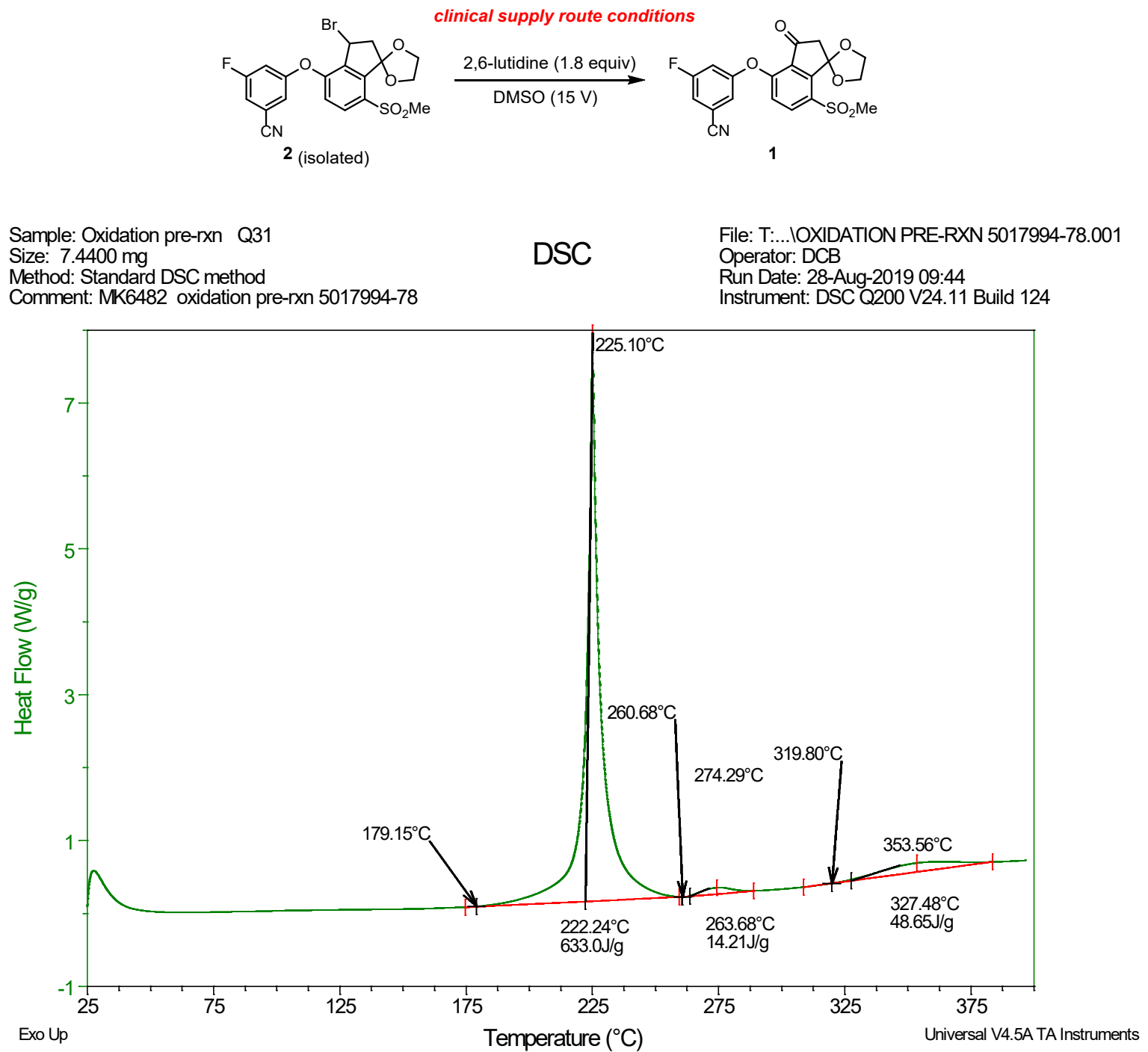

Figure S1. DSC analysis of the oxidation pre-reaction mixture using DMSO.

A sample of the oxidation pre-reaction solution containing isolated bromide 2, 2,6-lutidine, and DMSO was submitted for differential scanning calorimetry (DSC) analysis (Figure S1). The results showed a rapid exotherm of $633 \mathrm{~J} / \mathrm{g}$ at a temperature onset of $179{ }^{\circ} \mathrm{C}$, a slow exotherm of $14 \mathrm{~J} / \mathrm{g}$ at a temperature onset of $261{ }^{\circ} \mathrm{C}$, and a slow exotherm of $49 \mathrm{~J} / \mathrm{g}$ at a temperature onset of $320^{\circ} \mathrm{C}$. The large exotherm $(>400 \mathrm{~J} / \mathrm{g})$ was identified to be a potential thermal hazard, which could lead to a potential thermal runaway and catastrophic vessel failure if no adequate emergency venting is 
available. Thus, the oxidation conditions used in the clinical supply route presented a safety risk for scale-up.
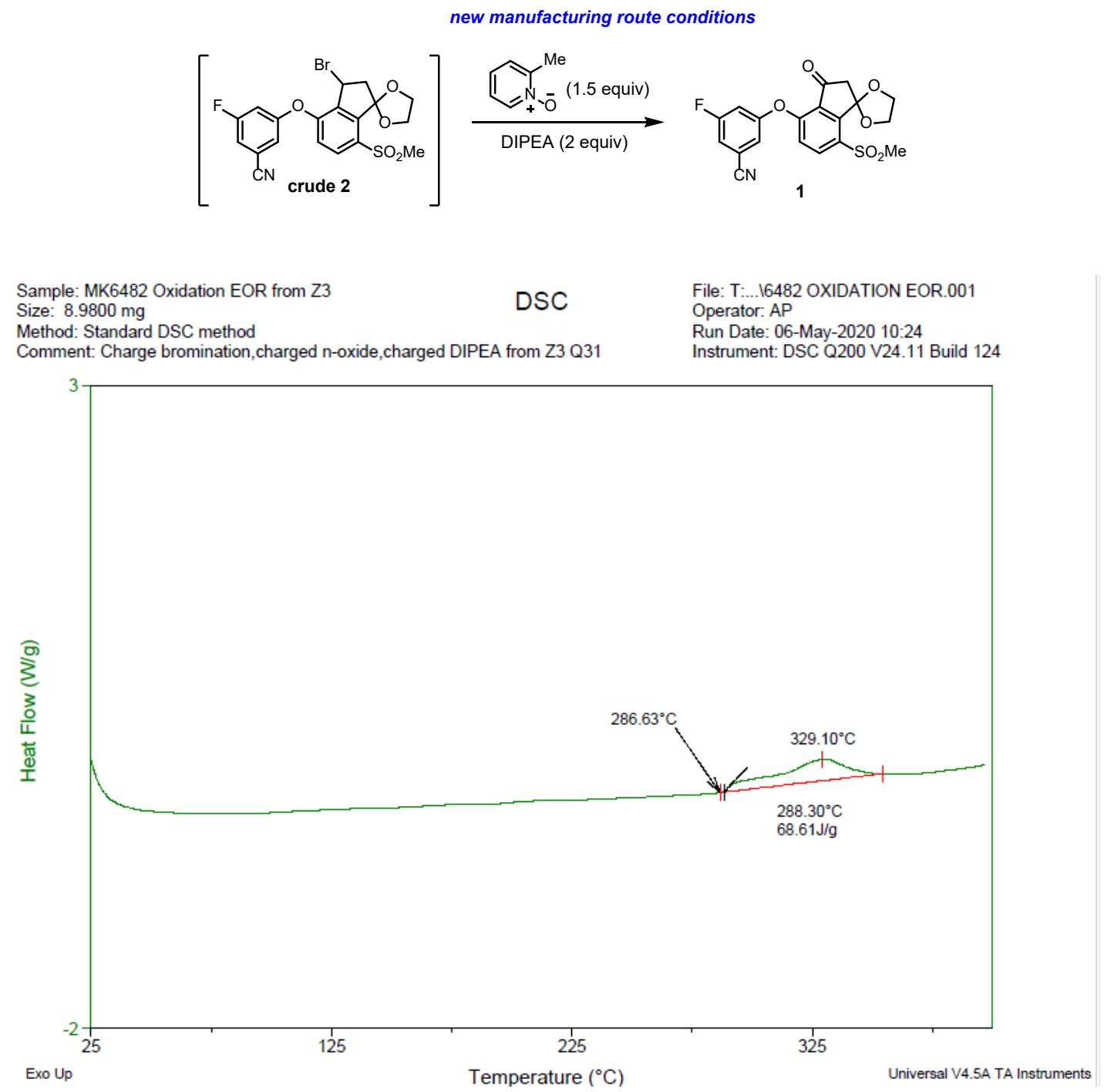

Figure S2. DSC for the pre-reaction mixture of the oxidation using 2-picoline $N$-oxide.

A sample of the oxidation pre-reaction mixture containing the quenched solution of bromide $\mathbf{2}$, 2-picoline $N$-oxide, DIPEA, and MeCN was submitted for differential scanning calorimetry (DSC) analysis (Figure S2). The results showed a slow exotherm of $69 \mathrm{~J} / \mathrm{g}$ at a temperature onset of 287 ${ }^{\circ} \mathrm{C}$. No potential hazards were identified with these conditions. 


\section{Stability of bromide 2 with various bases}

Table S1. Recovery of bromide 2 after aging with various bases. ${ }^{\text {a }}$

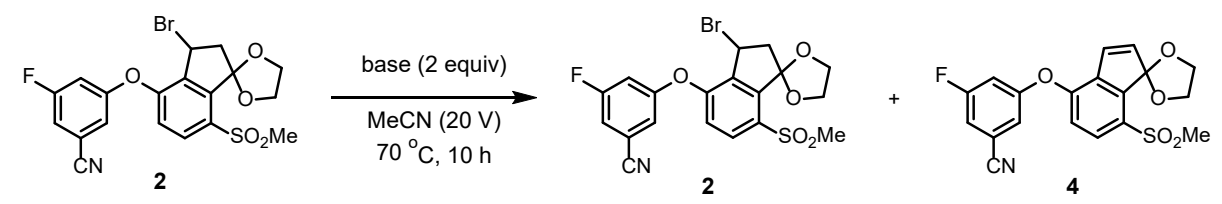

\begin{tabular}{ccccc}
\hline Entry & Base & $\begin{array}{c}\text { \% recovery } \\
\text { of } 2\end{array}$ & LCAP of 2 & LCAP of 4 \\
\hline 1 & $\mathrm{Et}_{3} \mathrm{~N}$ & 53 & 21 & 66 \\
2 & $\mathrm{Bu}_{3} \mathrm{~N}$ & 40 & 39 & 49 \\
3 & $\mathrm{Cy}_{2} \mathrm{NMe}$ & 48 & 47 & 48 \\
4 & $\mathrm{TMP}$ & 59 & 72 & 19 \\
5 & $\mathrm{Cy}_{2} \mathrm{NH}$ & 51 & 51 & 32 \\
6 & ${ }^{i} \mathrm{Pr}_{2} \mathrm{NH}$ & 69 & 70 & 23 \\
7 & $\mathrm{DIPEA}$ & 81 & 85 & 6 \\
8 & DIPEA (0.5 equiv) & 96 & 95 & 2 \\
9 & DIPEA (1 equiv) & 93 & 92 & 4 \\
10 & DIPEA (3 equiv) & 82 & 81 & 7 \\
\hline
\end{tabular}

a $\%$ recovery of bromide 2 calculated by quantitative liquid chromatography. LCAP (liquid chromatography area percent) was measured at $230 \mathrm{~nm}$.

The stability of bromide $\mathbf{2}$ in the presence of various bases were evaluated by aging a solution of $2 \mathrm{in} \mathrm{MeCN}$ with the appropriate loading of the base at $70{ }^{\circ} \mathrm{C}$ for $10 \mathrm{~h}$ (Table S1). Unsurprisingly, the major impurity formed is alkene 4 . In the cases of $\mathrm{Et}_{3} \mathrm{~N}, \mathrm{Bu}_{3} \mathrm{~N}$, and ${ }^{i} \mathrm{Pr}_{2} \mathrm{NH}$, up to $10 \mathrm{LCAP}$ of the corresponding quaternary ammonium (with $\mathrm{Et}_{3} \mathrm{~N}$ and $\mathrm{Bu}_{3} \mathrm{~N}$ ) or tertiary amine (with ${ }^{i} \operatorname{Pr}_{2} \mathrm{NH}$ ) resulting from bromide displacement was observed. Based on this study, DIPEA proved to be a promising base and afforded the least degradation of 2. Lower loadings of DIPEA proved to be beneficial for the stability of $\mathbf{2}$. Indeed, we observed a $90 \%$ assay yield of ketone $\mathbf{1}$ after oxidation using purified bromide 2, 1.3 equiv of DIPEA and 1.5 equiv of 2-picoline $N$-oxide. However, we observed that 2 equiv of DIPEA was needed to robustly achieve reaction completion using the crude quenched solution of 2 . 


\section{Investigation of other potential quench reagents and reverse quench stability.}
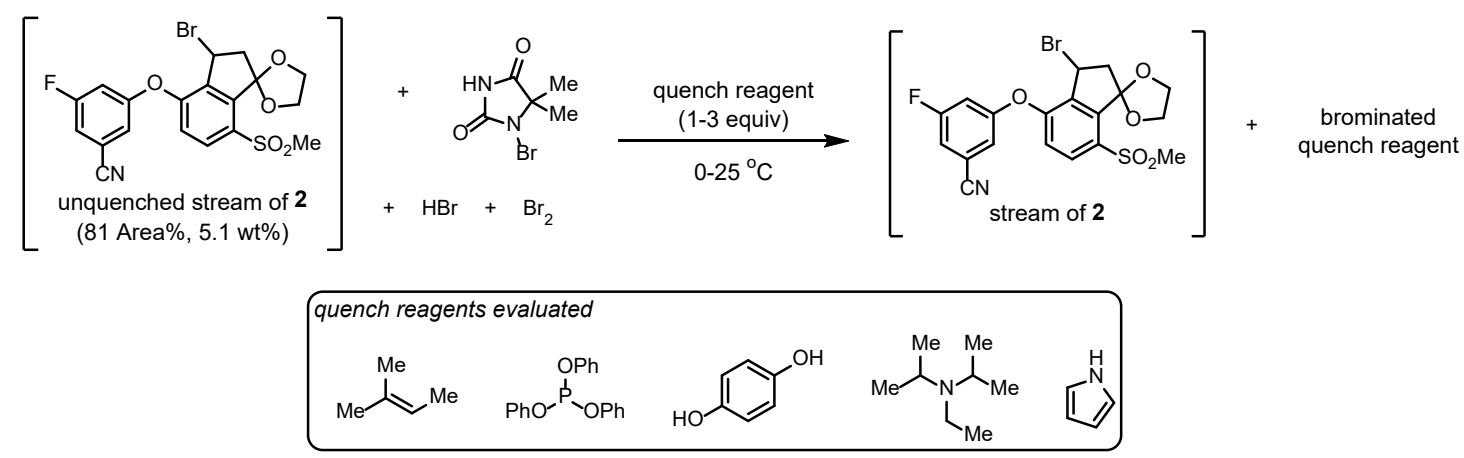

In addition to 1,3-dimethoxybenzene (DMB) and 2,6-lutidine, we evaluated 2-methyl-2-butene, triphenylphosphite, hydroquinone, DIPEA, and pyrrole as potential reagents to react with the leftover brominating species and $\mathrm{HBr}$ from the preceding photoflow bromination and quench the bromination end-of-reaction (EOR) stream. In the cases of pyrrole and DIPEA, bromide 2 was unstable in the resulting mixture upon aging at ambient temperature and $70{ }^{\circ} \mathrm{C}$. With hydroquinone, the brominated arene could be detected by LC in up to $39 \mathrm{Area} \%$, but 2 proved to be unstable in the resulting mixture upon aging at ambient temperature for $5 \mathrm{~h}$.

Treating the unquenched stream of bromide 2 with triphenylphosphite and 2,6-lutidine resulted in the formation of triphenylphosphate. However, additional impurities were formed presumably arising from displacement of the bromide with triphenylphosphite. Like the DMB/lutidine mixture, the combination of 2-methyl-2-butene and 2,6-lutidine imparted good stability to bromide 2 in the resulting stream at ambient temperature. However, the expected alkyl bromides resulting from bromination and/or hydrobromination were not detected by ${ }^{1} \mathrm{H}$ NMR. Since the exact species capturing bromine could not be identified and therefore monitored, we chose the DMB/lutidine mixture as our quench method. 
Table S2. Stability of bromide $\mathbf{2}$ during the reverse quench.

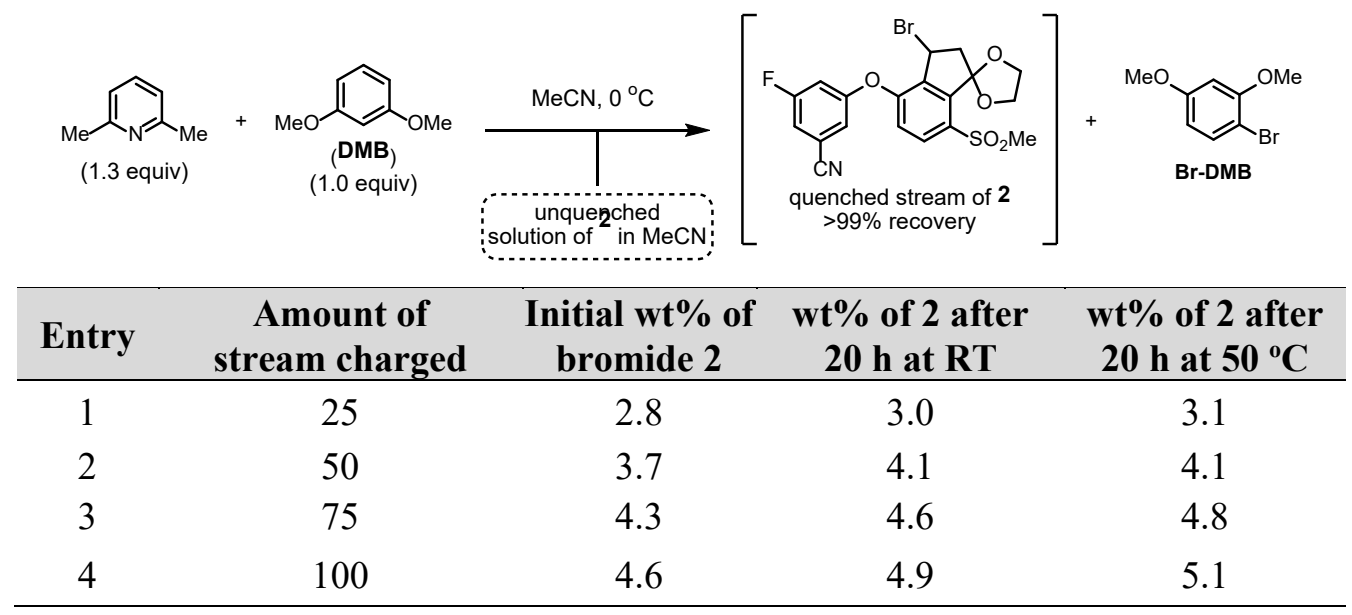

The stability of bromide 2 during the reverse quench was evaluated by monitoring the wt $\%$ of 2 upon aging a sample of the solution after each quarter of the unquenched stream was charged. As shown in table S2, bromide $\mathbf{2}$ was stable throughout the quench and fully recovered. In addition, the formation of $\mathrm{Br}_{2}-\mathrm{DMB}$ was suppressed.

\section{Additional oxidation optimization details}

\section{Base evaluation with pyridine $\mathrm{N}$-oxide}
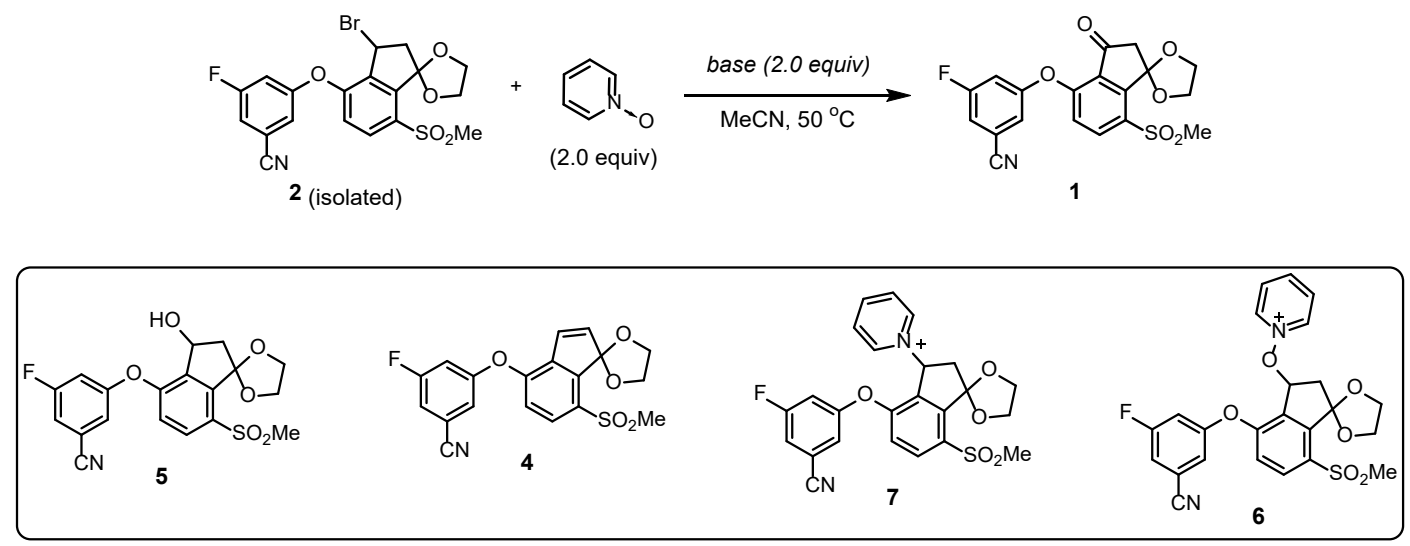

Bromide 2 (100 mg, 1 equiv), pyridine $N$-oxide (2.0 equiv), and $\operatorname{MeCN}(9 \mathrm{~V})$ were charged to a 1-dr vial equipped with a stir bar. The inorganic or organic base was added (2.0 equiv). For reactions using inorganic bases, $1 \mathrm{~V}$ of $\mathrm{H}_{2} \mathrm{O}$ was charged to improve the solubility of the base since 
$\mathrm{H}_{2} \mathrm{O}$ has no impact on the oxidation. The vial was sealed and allowed to stir overnight (15-22 h) at $50{ }^{\circ} \mathrm{C}$. The reaction mixtures were allowed to cool to RT and sampled for HPLC analysis.

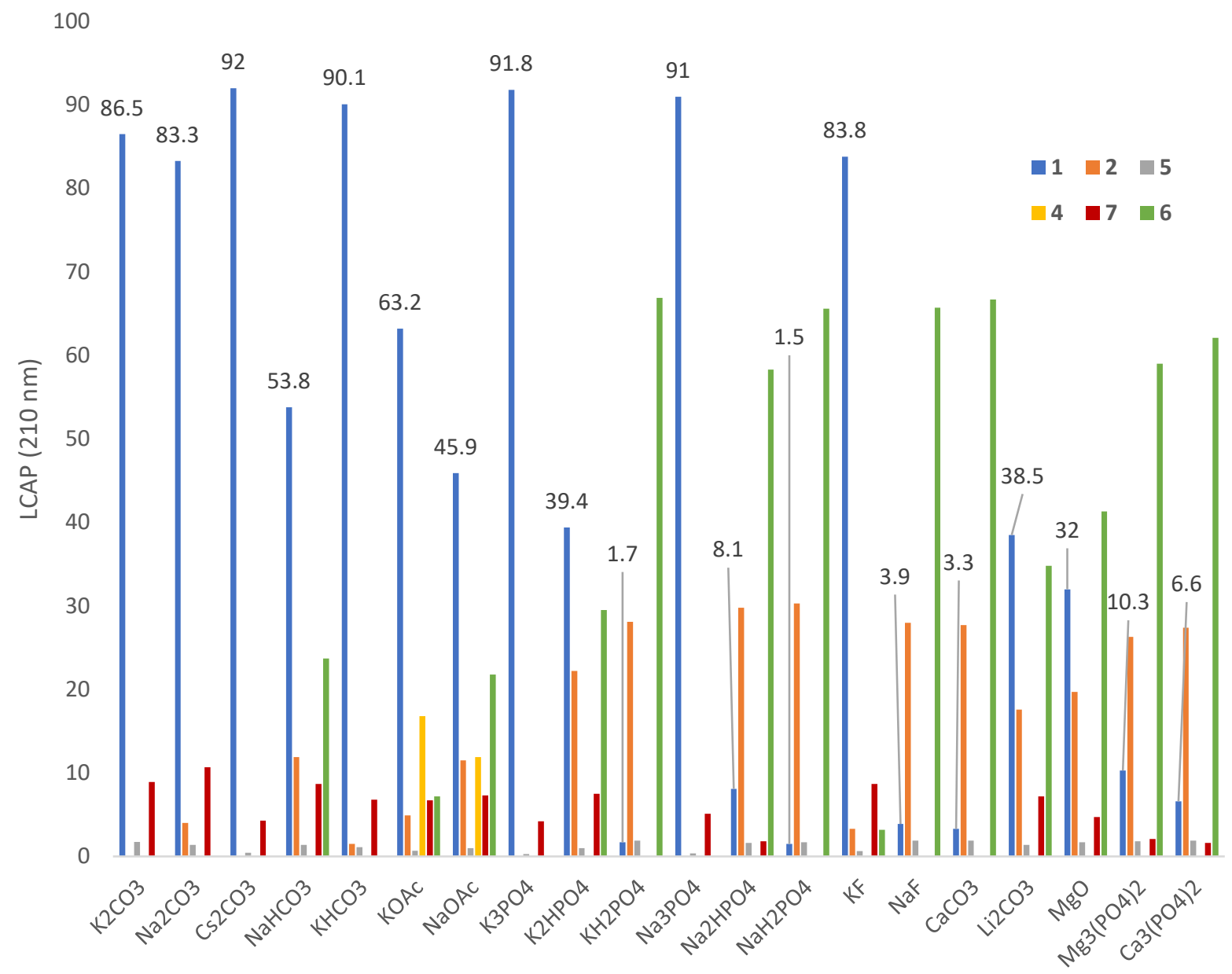

Figure S3. Optimization data with inorganic bases.

The oxidation of bromide 2 with pyridine $N$-oxide worked appreciably well with a variety of inorganic bases (Figure S3). Among the inorganic bases examined, $\mathrm{K}_{2} \mathrm{CO}_{3}, \mathrm{Na}_{2} \mathrm{CO}_{3}, \mathrm{C}_{2} \mathrm{CO}_{3}$, $\mathrm{KHCO}_{3}, \mathrm{~K}_{3} \mathrm{PO}_{4}, \mathrm{Na}_{3} \mathrm{PO}_{4}$, and $\mathrm{KF}$ afforded ketone 1 in 83-92 LCAP. Cognizant of potential scaleup variability due to the heterogeneity of the reaction mixture, $1 \mathrm{~V}$ of $\mathrm{H}_{2} \mathrm{O}$ was charged to these reactions to improve the solubility of the base since there was no impact of $\mathrm{H}_{2} \mathrm{O}$ to the oxidation. We next repeated some of these promising reactions (e.g. $\mathrm{C}_{2} \mathrm{CO}_{3}$ and $\mathrm{K}_{3} \mathrm{PO}_{4}$ ) on gram-scale with overhead stirring. Despite achieving a near-homogeneous reaction mixture at the reaction temperature, we observed lower conversions. Given the lower conversions on larger scales with 
overhead stirring, we next examined organic amine bases to achieve a homogeneous reaction mixture.

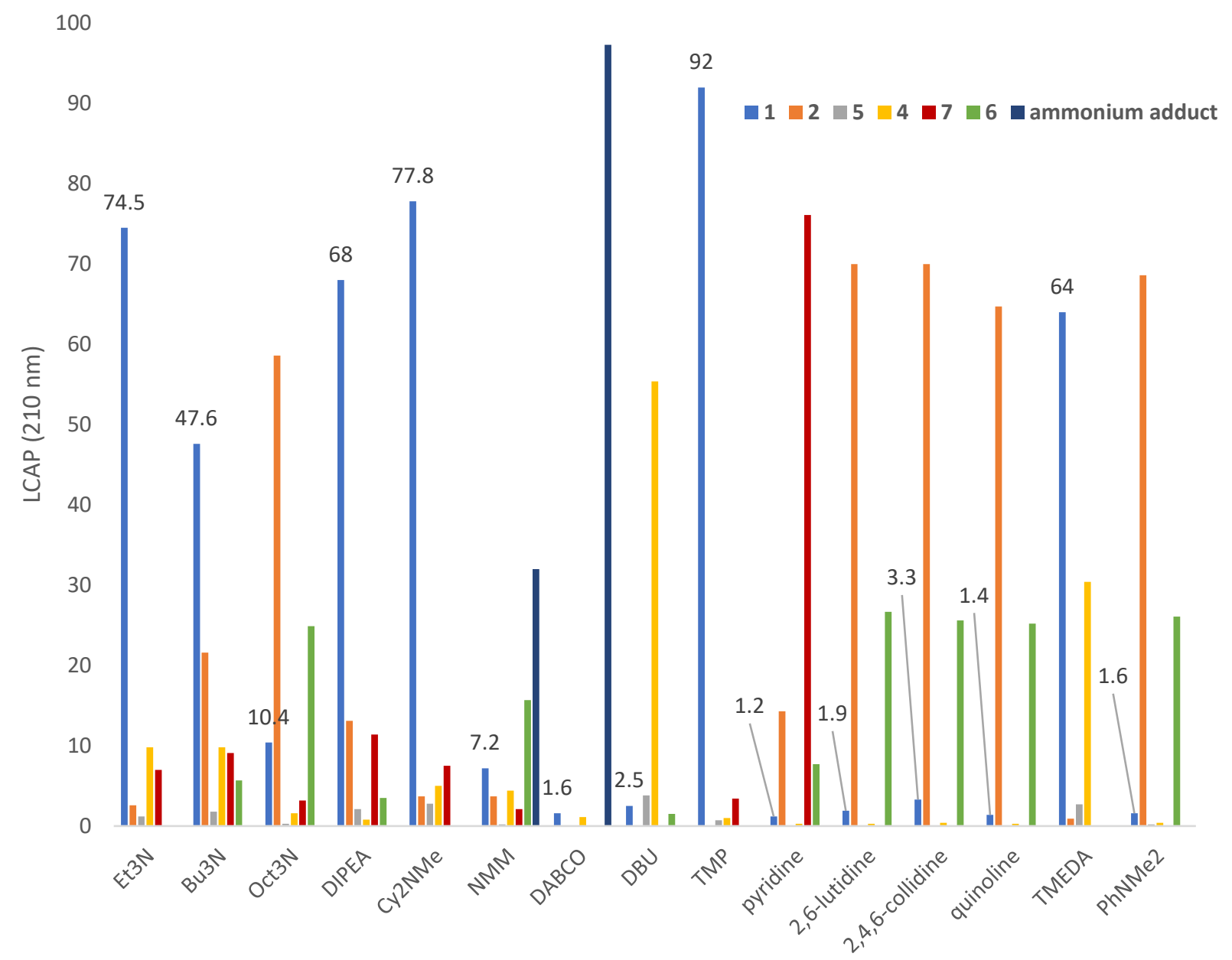

Figure S4. Optimization data with tertiary amines and pyridines.

On a small scale, TMP, $\mathrm{Cy}_{2} \mathrm{NH}$, and ${ }^{i} \mathrm{Pr}_{2} \mathrm{NH}$ showed promising results for the oxidation using pyridine $\mathrm{N}$-oxide (Figures S4 and S5). Competitive displacement of the bromide occurred with primary and sterically unhindered secondary amines such as piperidine, diethylamine, and butylamine, which generated the corresponding amine adducts. Of the tertiary amines examined, DABCO and NMM ( $N$-methylmorpholine) afforded significant levels of the corresponding quaternary ammonium species. Additional screening of various $N$-oxides with DIPEA revealed that the oxidation can afford $90 \%$ assay yield of ketone 1 with 2-picoline $N$-oxide, which is more readily available at scale. We chose DIPEA because it offered the most stability for bromide $\mathbf{2}$ (see 
Table S1) and a homogeneous reaction mixture with no precipitation of the $\mathrm{HBr}$ salt during the reaction.

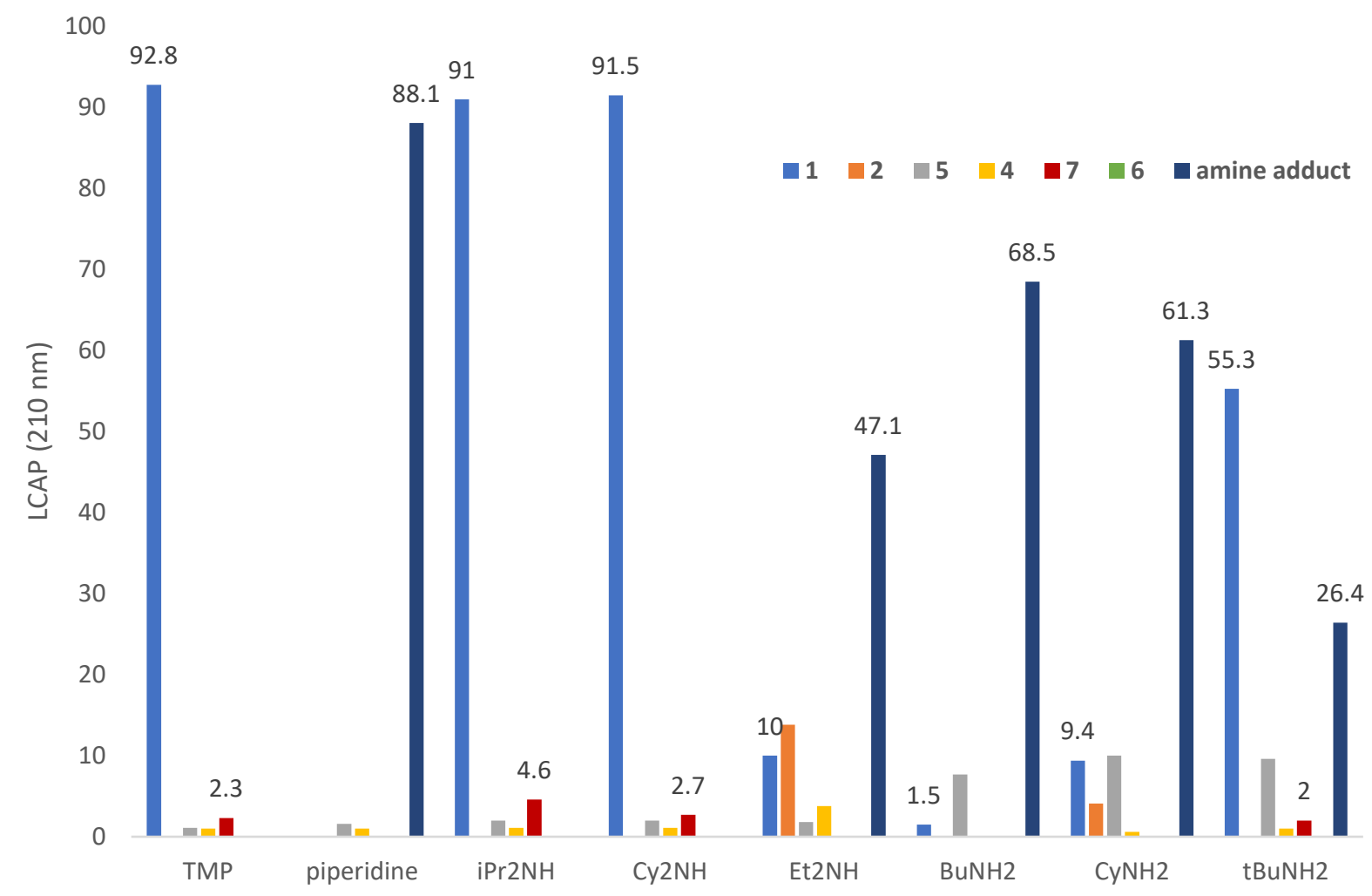

Figure S5. Optimization data with secondary and primary amines.

\section{$N$-oxide evaluation with DIPEA}

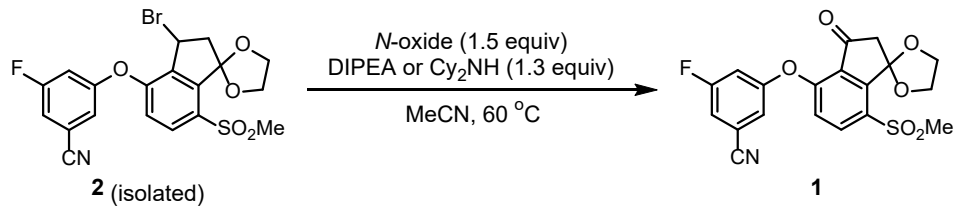

Bromide 2 ( $250 \mathrm{mg}, 0.518 \mathrm{mmol}, 1$ equiv) and the $N$-oxide (1.5 equiv) were charged to a $20-\mathrm{mL}$ vial equipped with a stir bar. MeCN $(5.0 \mathrm{~mL}, 20 \mathrm{~V})$ was added followed by DIPEA $(118 \mu \mathrm{L}, 0.673$ mmol, 1.3 equiv). The vial was sealed and allowed to stir overnight $(14-18 \mathrm{~h})$ at $60{ }^{\circ} \mathrm{C}$. The reaction mixtures were allowed to cool to RT and sampled for HPLC analysis. 


\section{Gram-scale oxidation and isolation with $\mathrm{H}_{2} \mathrm{O}$}

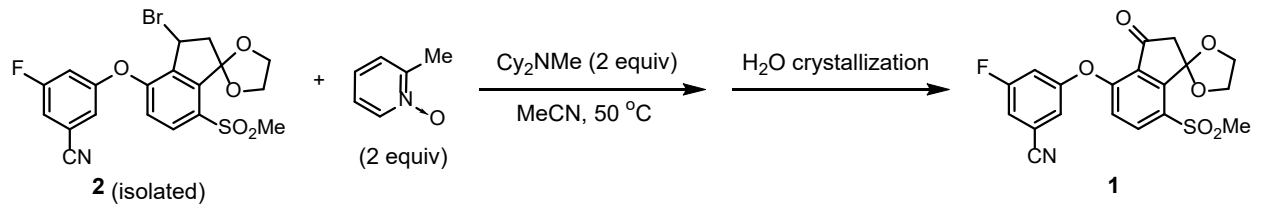

Bromide 2 (1.6 g, $3.11 \mathrm{mmol}, 1$ equiv), 2-picoline $N$-oxide (707 mg, $6.22 \mathrm{mmol}, 2.0$ equiv), and $\mathrm{MeCN}(16 \mathrm{~mL}, 10 \mathrm{~V})$ were charged to a $100-\mathrm{mL}$ reaction vessel. $\mathrm{Cy}_{2} \mathrm{NMe}(1.4 \mathrm{~mL}, 6.22 \mathrm{mmol})$ as added, and the resulting mixture was stirred for $17 \mathrm{~h}$ at $50{ }^{\circ} \mathrm{C}$. Ketone $\mathbf{1}(16.0 \mathrm{mg}, 1 \mathrm{wt} \%)$ was charged, and the resulting slurry was cooled to $30^{\circ} \mathrm{C}$ over $1 \mathrm{~h} . \mathrm{H}_{2} \mathrm{O}(24 \mathrm{~mL}, 15 \mathrm{~V})$ was charged over $1 \mathrm{~h}$. The batch was cooled to $20{ }^{\circ} \mathrm{C}$ over $1 \mathrm{~h}$ and aged at $20{ }^{\circ} \mathrm{C}$ for $3 \mathrm{~h}$. The product was collected by filtration, washed with 3:1 (v/v) $\mathrm{H}_{2} \mathrm{O}: \mathrm{MeCN}(4 \mathrm{~mL}, 2.5 \mathrm{~V})$, and dried under vacuum at RT. The isolated ketone 1 (1.27 g) was a dark brown solid with $86.6 \%$ purity and $82.0 \mathrm{wt} \%$ by quantitative ${ }^{1} \mathrm{H}$ NMR corresponding to a $83 \%$ isolated yield.

\section{Gram-scale oxidation and isolation with isopropanol (IPA)}

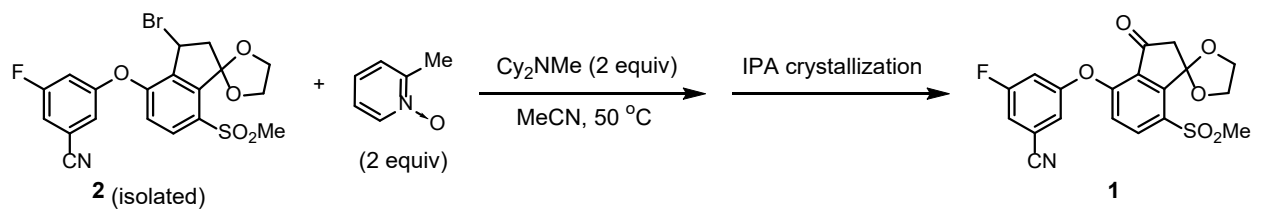

Bromide 2 (3.0 g, $6.27 \mathrm{mmol}, 1$ equiv), 2-picoline $N$-oxide (1.42 g, $12.5 \mathrm{mmol}, 2.0$ equiv), and $\mathrm{MeCN}(27 \mathrm{~mL}, 9 \mathrm{~V})$ were charged to a $100-\mathrm{mL}$ reaction vessel. $\mathrm{Cy}_{2} \mathrm{NMe}(2.8 \mathrm{~mL}, 12.5 \mathrm{mmol})$ as added, and the resulting mixture was stirred for $1.5 \mathrm{~h}$ at $50^{\circ} \mathrm{C}$ at which point $30 \mathrm{mg}$ of $1(1 \mathrm{wt} \%)$ was charged. The resulting mixture was stirred at $50{ }^{\circ} \mathrm{C}$ for another $17 \mathrm{~h}$. IPA $(36 \mathrm{~mL}, 12 \mathrm{~V})$ was charged over $2 \mathrm{~h}$. The batch was cooled to $20^{\circ} \mathrm{C}$ over $3 \mathrm{~h}$ and aged at $20^{\circ} \mathrm{C}$ for $1 \mathrm{~h}$. The product was collected by filtration, washed twice with 3:1 (v/v) IPA:MeCN (9 mL, $3 \mathrm{~V})$, and dried under vacuum at RT. The isolated ketone 1 (1.78 g) was a light brown solid with $97.5 \%$ purity and 97 wt $\%$ by quantitative ${ }^{1} \mathrm{H}$ NMR corresponding to a $68 \%$ isolated yield. 
Table S3. Examination of reagent loadings, temperature, and batch volume on the oxidation. ${ }^{\text {a }}$

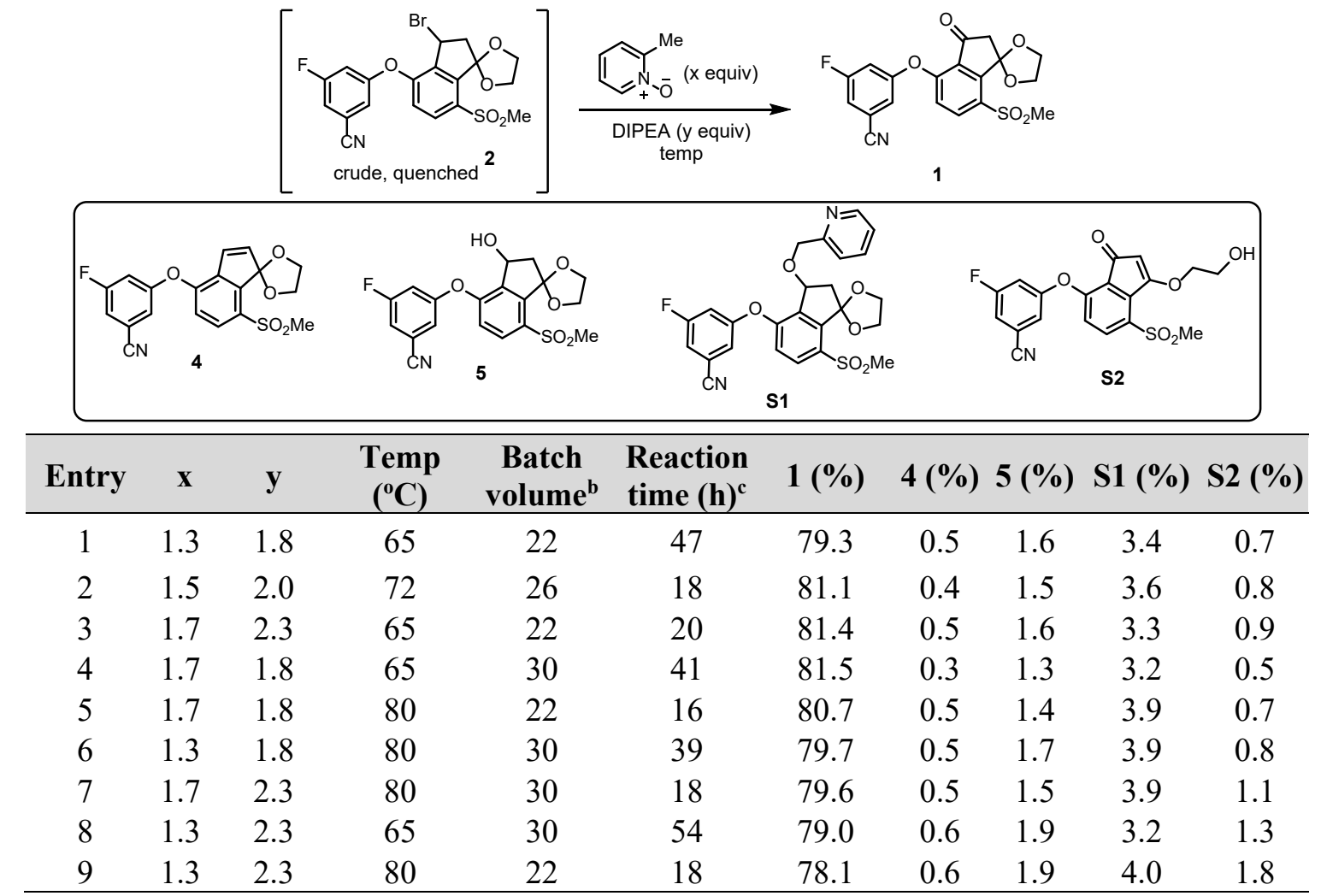

${ }^{a}$ Percentages $(\%)$ were determined by liquid chromatography and correspond to area percent. ${ }^{b}$ Batch volume is with respect to bromide $2 .{ }^{c}$ Reaction age was stopped after at least $99 \%$ conv was obtained.

We examined the effect of reagent loadings and temperature on the oxidation using the quenched solution of bromide $\mathbf{2}$ (Table S3). In addition to $\mathbf{4}$ and 5, we monitored the levels of impurities S1 and $\mathbf{S 2}$ which arise from decomposition of the pyridine $N$-oxide intermediate analogous to $\mathbf{6}$ and ketone 1 respectively. We examined a range of 1.3-1.7 equiv for the $N$-oxide, $1.8-2.3$ equiv for DIPEA, $65-80{ }^{\circ} \mathrm{C}$ for temperature, and $22-30 \mathrm{~V}$ for batch volume. Although lower reagent loadings and temperature led to longer reaction age times, the levels of ketone $\mathbf{1}$ are similar after extended aging. Higher loadings of DIPEA and temperature led to increased impurity levels such as S2. For improved reaction performance, the oxidation can be carried out at lower temperatures, lower loadings of DIPEA, and higher loadings of the $N$-oxide. 


\section{Typical procedures for the oxidation}

\section{Kilogram-scale through-process oxidation with isolation A}
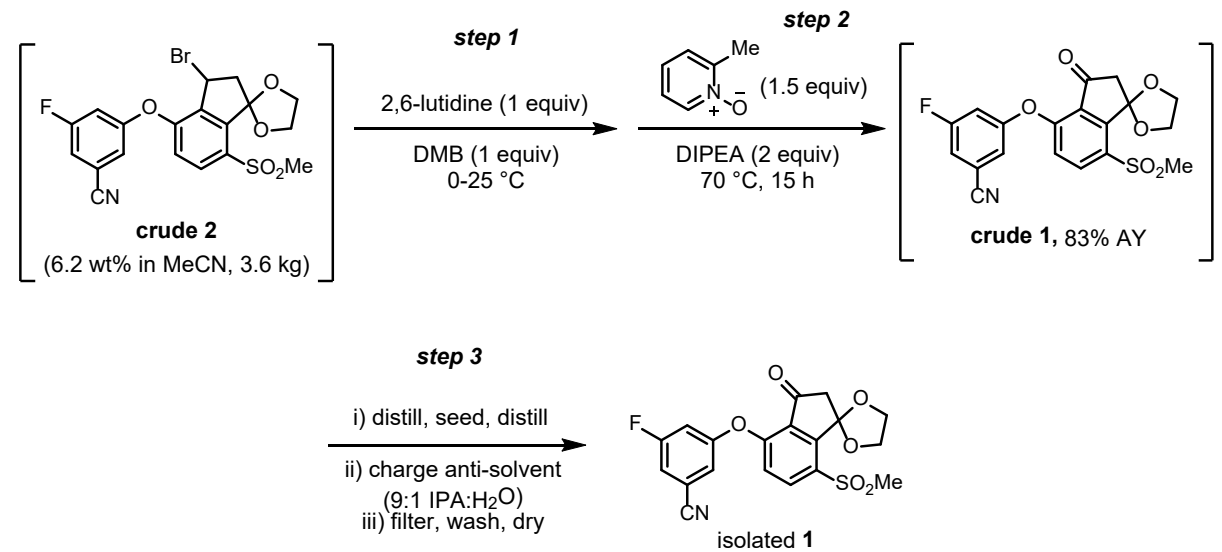

Step 1 (Quench). A $100 \mathrm{~L}$ jacketed cylindrical vessel was purged with high $\mathrm{N}_{2}$ flow after cleaning. Anhydrous MeCN (3 vol, 10.6 L), 2,6-lutidine (896 mL, 1.0 equiv), 1,3dimethoxybenzene (DMB) (1.0 L, 1.0 equiv) were added to the vessel, and the resulting mixture was agitated to achieve a homogeneous solution. The jacket temperature $(\mathrm{Tj})$ was set to $-5{ }^{\circ} \mathrm{C}$, with a $\operatorname{Tr}$ (internal temperature) setpoint goal of $0-5{ }^{\circ} \mathrm{C}$. The crude EOR solution containing bromide 2 $(6.21 \mathrm{wt} \%, 3.5 \mathrm{~kg}$ of 2$)$ was charged into the reactor using a peristaltic pump at a rate of $30-50$ $\mathrm{L} / \mathrm{h}$. The reverse addition was completed after $1.3 \mathrm{~h}$, and $\operatorname{Tr}$ was below $5{ }^{\circ} \mathrm{C}$ during the addition. Tr was increased to $25^{\circ} \mathrm{C}$, and the resulting brown solution was aged for $30 \mathrm{~min}$ at $25{ }^{\circ} \mathrm{C}$.

Step 2 (Oxidation). DIPEA (2.65 L, 2.0 equiv) and 2-picoline $N$-oxide $(1.88 \mathrm{~kg}, 65.6 \mathrm{wt} \%$ in $\mathrm{MeCN}, 1.5$ equiv) were charged to the reactor. $\mathrm{Tj}$ was set to $90{ }^{\circ} \mathrm{C}$ and then to $75^{\circ} \mathrm{C}$ to target a $\mathrm{Tr}$ of $68-72{ }^{\circ} \mathrm{C}$. The dark homogeneous solution was aged at $71{ }^{\circ} \mathrm{C}$ for $15 \mathrm{~h}$. Step 3 (Isolation). The reactor was equipped with a batch concentrator, and $\operatorname{Tr}$ was lowered to $46^{\circ} \mathrm{C}$. The batch was concentrated under vacuum (23 in $\mathrm{Hg}$ ) to $\sim 83 \mathrm{~L}$ and seeded with $21.1 \mathrm{~g}(1.0 \mathrm{wt} \%)$ of ketone 1. After aging for $12 \mathrm{~min}$ at $44{ }^{\circ} \mathrm{C}(\mathrm{Tr})$, the batch was further concentrated under vacuum $(23 \mathrm{in} \mathrm{Hg})$ to $\sim 14 \mathrm{~L}(4 \mathrm{~V})$ at $44-45{ }^{\circ} \mathrm{C}(\mathrm{Tr}) .38 .8 \mathrm{~L}$ of $9: 1 \mathrm{IPA}: \mathrm{H}_{2} \mathrm{O}$ was charged to the batch at $\mathrm{Tr}=45^{\circ} \mathrm{C}$ over 2 hours using a peristaltic pump. The batch was aged for $3 \mathrm{~h}$ at $40-45^{\circ} \mathrm{C}$, cooled to $25^{\circ} \mathrm{C}$ over $3 \mathrm{~h}$, and aged at $25^{\circ} \mathrm{C}$ for $9 \mathrm{~h}$. The mother liquor concentration was determined by HPLC to be $8.7 \mathrm{mg} / \mathrm{mL}$. The slurry was vacuum filtered into a filter pot. The cake was slurry washed four times 
with 3:7 MeCN:IPA (2 V, 7.0 L). After drying under vacuum and $\mathrm{N}_{2}$ sweep at RT for 3 days, 2.03 $\mathrm{kg}$ of ketone 1 was isolated with $98.7 \%$ purity $(97.8 \mathrm{wt} \%$ ) corresponding to a $65 \%$ isolated yield.

\section{Through-process oxidation with isolation $\mathrm{B}^{2}$}
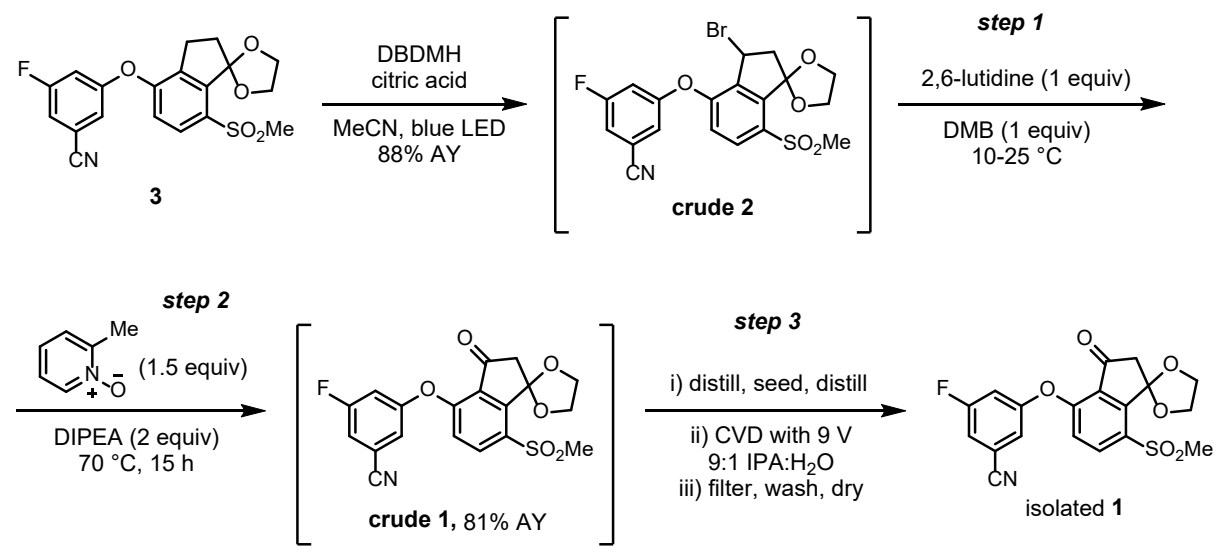

Step 1 (Quench). A 1 L jacketed cylindrical vessel was charged with DMB (1,3dimethoxybenzene, $15.3 \mathrm{~mL}, 1.0$ equiv), 2,6-lutidine (13.6 mL, 1.0 equiv), and $\mathrm{MeCN}(40 \mathrm{~mL}$ ). The crude EOR solution containing bromide 2 ( $5.23 \mathrm{wt} \%, 48 \mathrm{~g}$ of 2 ) was charged into the reactor using a peristaltic pump at $0{ }^{\circ} \mathrm{C}$. The resulting solution was warmed to $25^{\circ} \mathrm{C}$ and aged for $30 \mathrm{~min}$ at $25^{\circ} \mathrm{C}$.

Step 2 (Oxidation). DIPEA (41 mL, 2.0 equiv) and 2-picoline $N$-oxide (33 g, $57.9 \mathrm{wt} \%$ in $\mathrm{MeCN}, 1.5$ equiv) were charged to the reactor. The dark homogeneous solution was aged at $70^{\circ} \mathrm{C}$ for $16 \mathrm{~h}$. Step 3 (Isolation). Tr was lowered to $40{ }^{\circ} \mathrm{C}$, and the batch was concentrated under vacuum $(190 \mathrm{~mm} \mathrm{Hg})$ to $\sim 1.0 \mathrm{~L}$. The batch was seeded with $1.0 \mathrm{~g}(2.0 \mathrm{wt} \%)$ of ketone 1 . After aging for $20 \mathrm{~min}$ at $40{ }^{\circ} \mathrm{C}(\mathrm{Tr})$, the batch was further concentrated under vacuum $(160-170 \mathrm{~mm}$ $\mathrm{Hg}$ ) to $\sim 400 \mathrm{~mL}(8 \mathrm{~V})$ at $40{ }^{\circ} \mathrm{C}(\mathrm{Tr}) .450 \mathrm{~mL}$ of $9: 1 \mathrm{IPA}: \mathrm{H}_{2} \mathrm{O}$ was charged to the batch at $40{ }^{\circ} \mathrm{C}$ while solvent was continuously removed via vacuum distillation (pressure $=165 \mathrm{~mm} \mathrm{Hg}$ ). The batch volume was maintained between 7-9 $\mathrm{V}$ throughout the anti-solvent addition. After the complete addition of the anti-solvent, the solvent ratio was determined to be 3.9:1 IPA:MeCN (w/w) by ${ }^{1} \mathrm{H}$ NMR. The batch was cooled to $25^{\circ} \mathrm{C}$ over $3 \mathrm{~h}$ and aged at $25^{\circ} \mathrm{C}$ for $15 \mathrm{~h}$. The mother liquor concentration was determined by HPLC to be $5.6 \mathrm{mg} / \mathrm{mL}$. The slurry was vacuum filtered, and the cake was slurry washed four times with 2:8 MeCN:IPA (3 V, $150 \mathrm{~mL})$. After drying under 
vacuum and $\mathrm{N}_{2}$ at $50{ }^{\circ} \mathrm{C}$ for $6 \mathrm{~h}, 35.3 \mathrm{~g}$ of ketone 1 was isolated with $98.5 \%$ purity (97.6 wt $\%$ ) corresponding to a $73 \%$ isolated yield over 2 steps from ketal 3 .

\section{Polymorph screen of ketone 1}

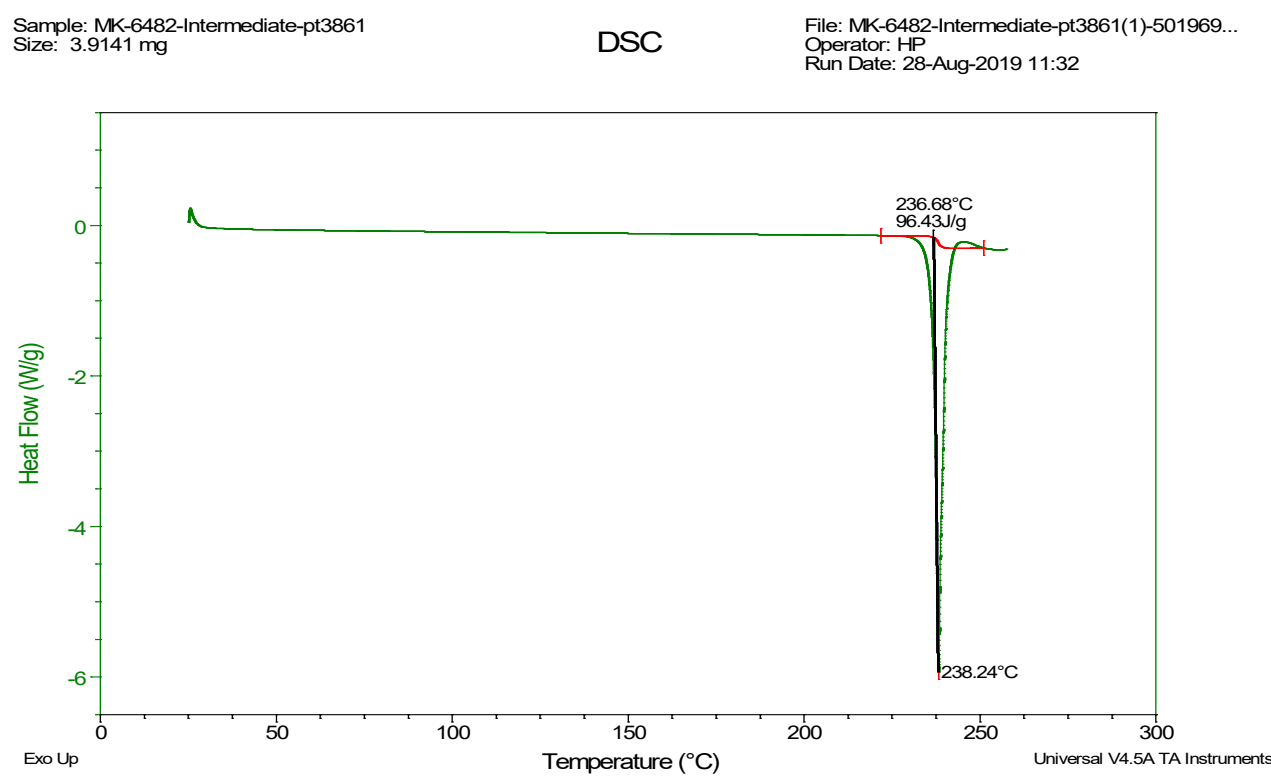

Figure S6. DSC of ketone 1.

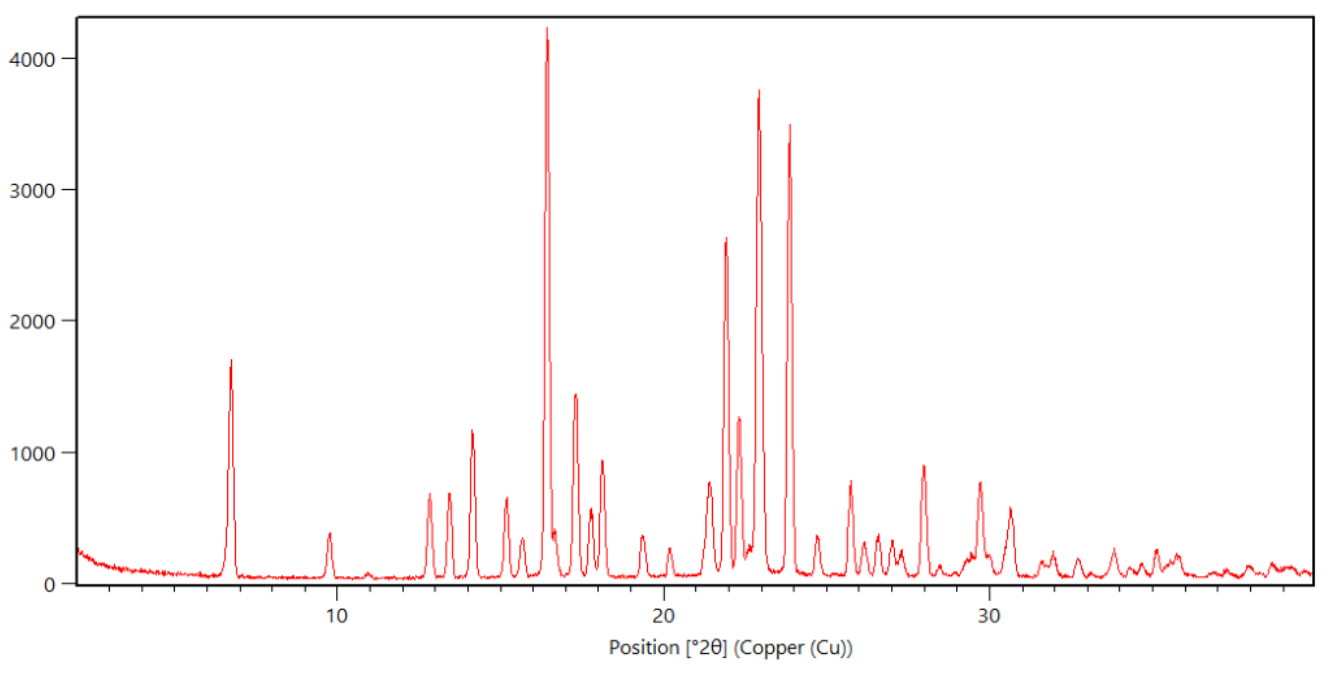

Figure S7. X-Ray Powder Diffraction (XRPD) of ketone 1 (Form A). 


\begin{tabular}{|c|c|c|}
\hline Pos. $\left[{ }^{\circ} 2 \theta\right]$ & $\begin{array}{c}\text { d-spacing } \\
{[\AA \AA}\end{array}$ & $\begin{array}{c}\text { Relative } \\
\text { Intensity }\end{array}$ \\
\hline 6.73 & 13.13 & $40 \%$ \\
\hline 9.76 & 9.06 & $8 \%$ \\
\hline 12.82 & 6.90 & $16 \%$ \\
\hline 13.43 & 6.59 & $16 \%$ \\
\hline 14.15 & 6.26 & $26 \%$ \\
\hline 15.19 & 5.83 & $14 \%$ \\
\hline 15.67 & 5.65 & $7 \%$ \\
\hline 16.43 & 5.40 & $100 \%$ \\
\hline 17.32 & 5.12 & $34 \%$ \\
\hline 17.77 & 4.99 & $13 \%$ \\
\hline 18.13 & 4.89 & $22 \%$ \\
\hline 19.36 & 4.58 & $8 \%$ \\
\hline 20.19 & 4.40 & $5 \%$ \\
\hline 21.42 & 4.15 & $18 \%$ \\
\hline 21.92 & 4.06 & $62 \%$ \\
\hline 22.32 & 3.98 & $29 \%$ \\
\hline 22.84 & 3.89 & $52 \%$ \\
\hline 22.93 & 3.88 & $90 \%$ \\
\hline 23.87 & 3.73 & $83 \%$ \\
\hline 24.72 & 3.60 & $7 \%$ \\
\hline 25.74 & 3.46 & $18 \%$ \\
\hline 26.16 & 3.41 & $6 \%$ \\
\hline 26.58 & 3.35 & $7 \%$ \\
\hline 27.01 & 3.30 & $7 \%$ \\
\hline 27.28 & 3.27 & $5 \%$ \\
\hline 27.99 & 3.19 & $21 \%$ \\
\hline
\end{tabular}


Table S4. Stress polymorph screen with ketone 1 .

\begin{tabular}{|c|c|c|c|c|}
\hline Entry & Solvent & $\begin{array}{l}\text { Temperature } \\
\left({ }^{\circ} \mathrm{C}\right)\end{array}$ & State & XPRD result \\
\hline 1 & Ethyl acetate (EtOAc) & 50 & Slurry & Form A \\
\hline 2 & Isopropanol (IPA) & 50 & Slurry & Form A \\
\hline 3 & Acetone & 25 & Slurry & Form A \\
\hline 4 & Dichloromethane & 6 & Slurry & Form A \\
\hline 5 & Acetonitrile $(\mathrm{MeCN})$ & 50 & Slurry & Form A \\
\hline 6 & Tetrahydrofuran (THF) & 25 & Slurry & Form A \\
\hline 7 & Water $\left(\mathrm{H}_{2} \mathrm{O}\right)$ & 25 & Slurry & Form A \\
\hline 8 & $\mathrm{H}_{2} \mathrm{O}: \mathrm{MeOH}(1: 3 \mathrm{v} / \mathrm{v})$ & 25 & Slurry & Form A \\
\hline 9 & $\mathrm{H}_{2} \mathrm{O}: \mathrm{MeCN}(1: 3 \mathrm{v} / \mathrm{v})$ & 6 & Slurry & Form A \\
\hline 10 & DME & 25 & Slurry & Form A \\
\hline 11 & Ethanol & 50 & Slurry & Form A \\
\hline 12 & 2-MeTHF & 25 & Slurry & Form A \\
\hline 13 & Dioxane & 6 & Slurry & Form A \\
\hline 14 & Toluene & 50 & Slurry & Form A \\
\hline 15 & Methanol (MeOH) & 25 & Slurry & Form A \\
\hline 16 & $\begin{array}{c}\text { EtOAc with } 10 \text { vol } \% \mathrm{HCO}_{2} \mathrm{H} \\
\text { and } 10 \mathrm{vol} \% \mathrm{Et}_{3} \mathrm{~N}\end{array}$ & 50 & Slurry & Form A \\
\hline 17 & 2:1 IPA:MeCN (v/v) & 5 & Slurry & Form A \\
\hline 18 & 2:1 IPA:MeCN (v/v) & 50 & Slurry & Form A \\
\hline 19 & $2: 110 \%$ aq. IPA:MeCN (v/v) & 5 & Slurry & Form A \\
\hline 20 & $10 \%$ aq IPA & 5 & Slurry & Form A \\
\hline
\end{tabular}

A polymorph screen from aging 1 with various solvents showed that there was only one anhydrous crystalline form (Form A) for ketone 1. Further screening with process related solvents (Table S4, entries 17-20) showed that there is no risk of a new form.

\section{Solubility and stability data for ketone 1}

Table S5. Solubility of ketone 1 in the oxidation EOR solution.

\begin{tabular}{cccc}
\hline Entry & Temperature $\left({ }^{\mathbf{}} \mathbf{C}\right)$ & $\begin{array}{c}\text { Solubility of } \mathbf{1} \\
(\mathbf{m g} / \mathbf{m L})\end{array}$ & $\begin{array}{c}\text { Soluble batch } \\
\text { volume }(\mathbf{m L} / \mathbf{g})^{\boldsymbol{a}}\end{array}$ \\
\hline 1 & 25 & 19.7 & 36 \\
2 & 40 & 29.4 & 24 \\
3 & 50 & 40.6 & 18 \\
4 & 60 & 55.2 & 13 \\
5 & 70 & 64.0 & 11 \\
\hline \multicolumn{2}{c}{ batch volume calculated relative to bromide 2 based on a 83\% assay yield. }
\end{tabular}




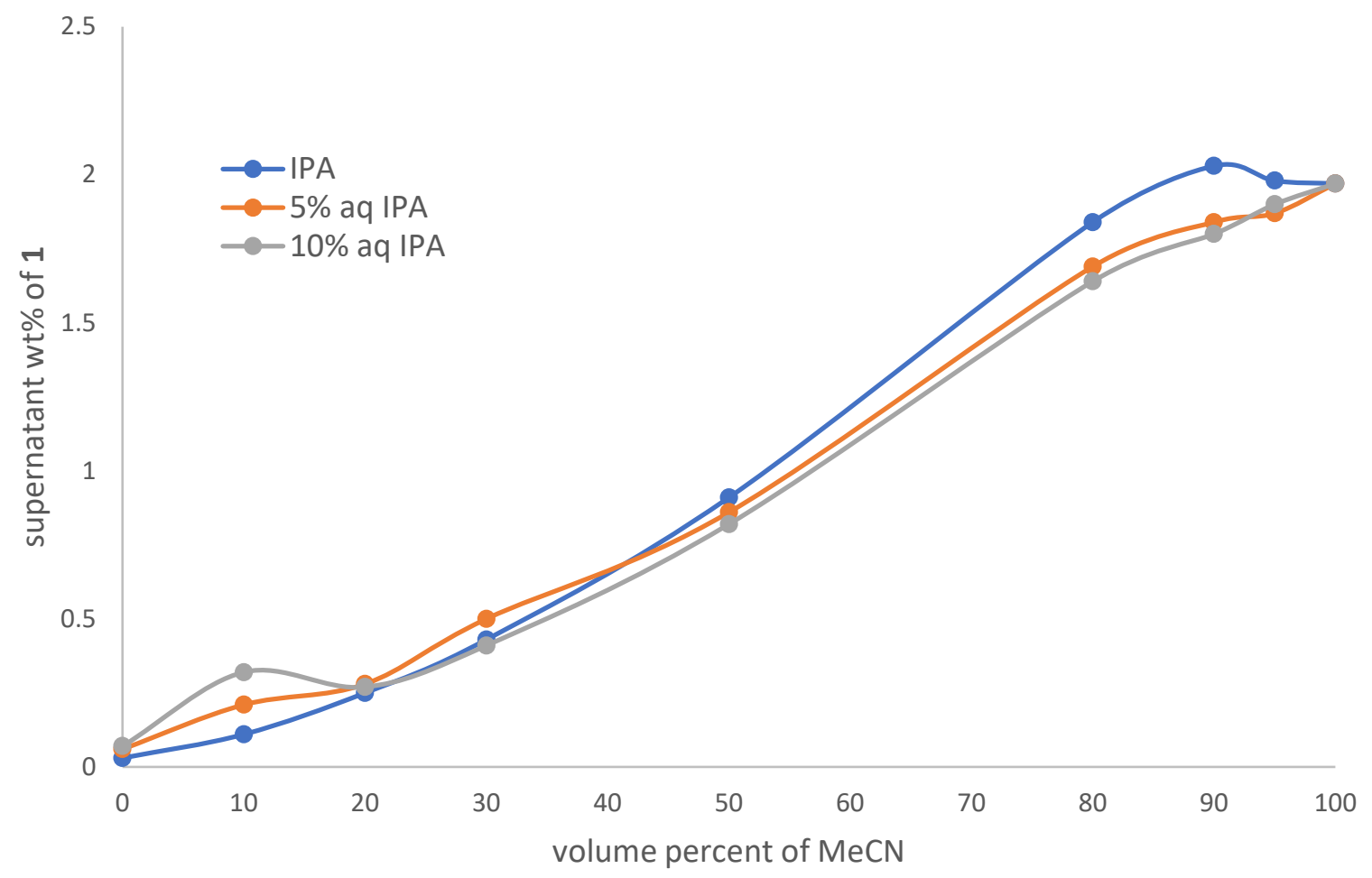

Figure S8. Solubility curves of $\mathbf{1}$ in $\mathrm{MeCN}$ and (aqueous) IPA.

Based on the solubility data, the oxidation EOR stream is saturated in ketone $\mathbf{1}$ at $24 \mathrm{~V}$ relative to bromide 2 . Since the batch begins to self-seeds at $\sim 13 \mathrm{~V}\left(40{ }^{\circ} \mathrm{C}\right)$, we chose to distill the batch to $18 \mathrm{~V}$ prior to seeding to ensure that the seeds hold within the temperature range of $35-45^{\circ} \mathrm{C}$. As shown in Figure S8, the solubility of ketone 1 increases with higher amounts of water in the IPA at $\sim 10 \mathrm{vol} \% \mathrm{MeCN}$. This is consistent with our observations that higher liquor concentrations were obtained when the $\mathrm{MeCN}$ content was low after the distillative crystallization. With 10\% aqueous IPA as the anti-solvent, a local solubility minimum was observed at $\sim 20$ vol\% $\mathrm{MeCN}$, so we targeted that composition for the constant volume distillation.

Table S6. Stability of ketone 1 in the oxidation EOR solution.

\begin{tabular}{ccccc}
\hline Entry & Time (days) & wt\% of $\mathbf{1}$ at RT & wt\% of $\mathbf{1}$ at $50{ }^{\circ} \mathbf{C}$ & wt\% of $\mathbf{1}$ at $\mathbf{7 0}{ }^{\circ} \mathbf{C}$ \\
\hline 1 & 0 & 3.22 & 3.22 & 3.22 \\
2 & 4 & 3.25 & 3.22 & 3.16 \\
3 & 15 & 3.32 & 3.19 & 3.18 \\
\hline
\end{tabular}


Table S7. Stability of ketone 1 at $8 \mathrm{~V}$ of oxidation EOR.

\begin{tabular}{ccccc}
\hline Entry & Time (days) & wt\% of $\mathbf{1}$ at RT & wt\% of $\mathbf{1}$ at $50^{\circ} \mathbf{C}$ & wt\% of $\mathbf{1}$ at $\mathbf{7 0}{ }^{\circ} \mathbf{C}$ \\
\hline 1 & 0 & 10.4 & 10.6 & 10.5 \\
2 & 2 & 10.4 & 10.7 & 10.5 \\
3 & 13 & 10.5 & 10.5 & 10.7 \\
\hline
\end{tabular}

Table S8. Stability of ketone 1 after constant volume distillation (3.4:1 v/v IPA:MeCN).

\begin{tabular}{ccccc}
\hline Entry & Time (days) & wt\% of $\mathbf{1}$ at RT & wt\% of $\mathbf{1}$ at $\mathbf{5 0}{ }^{\circ} \mathbf{C}$ & wt\% of $\mathbf{1}$ at $70{ }^{\circ} \mathbf{C}$ \\
\hline 1 & 0 & 8.60 & 8.52 & 8.46 \\
2 & 2 & 8.51 & 8.49 & 8.55 \\
3 & 13 & 8.67 & 8.50 & 8.48 \\
\hline
\end{tabular}

As shown by the data in Tables S6-8, ketone 1 is stable in the oxidation EOR stream for up to 15 days at temperatures up to $50{ }^{\circ} \mathrm{C}$. In addition, 1 proved to be stable in the concentrated EOR stream and after constant volume distillation for up to 13 days.

\section{HPLC analytical method and chromatograms}

$\underline{\text { Chromatographic Conditions }}$

Column:

Detector:

Temperature:

Flow rate:

Injection Volume:

Sample Tray Temperature:

Needle wash:

Stock Buffer Solution:

Mobile Phase Program:

Post Time: $2 \mathrm{~min}$
Agilent Poroshell 120 Bonus-RP (2.1 x 100 mm, $2.7 \mu \mathrm{m})$ (Part \# 695768-901T)

$\mathrm{UV}$ at $210 \mathrm{~nm}$

$55^{\circ} \mathrm{C}$

$0.5 \mathrm{~mL} / \mathrm{min}$

$2 \mu \mathrm{L}$

$10{ }^{\circ} \mathrm{C}$

$\mathrm{MeCN}$

Mobile Phase A: $0.1 \% \mathrm{H}_{3} \mathrm{PO}_{4}$ in water (v/v)

Mobile Phase B: 2:8 MeCN:MeOH (v/v)

$\begin{array}{cc}\frac{\text { Time }(\min )}{0} & \frac{\% \mathrm{~B}}{10} \\ 1 & 10 \\ 10 & 46 \\ 16 & 95 \\ 19 & 95 \\ 19.1 & 10 \\ 24 & 10\end{array}$


Table S9. Approximate Relative Retention Times for Product and Impurities.

\begin{tabular}{|c|c|c|c|}
\hline Name & RT & $\mathrm{RRT}^{\mathrm{a}}$ & Structure \\
\hline Pyridyl ketal S1 & 5.79 & 0.74 & \\
\hline $\begin{array}{l}\text { 1,3-dimethoxybenzene } \\
\text { (DMB) }\end{array}$ & 6.10 & 0.78 & \\
\hline alcohol 5 & 7.32 & 0.93 & \\
\hline ketone 1 & 7.83 & 1.0 & \\
\hline glycol enol ether $\mathbf{S 2}$ & 8.36 & 1.07 & \\
\hline $\begin{array}{l}\text { 1-bromo-2,4- } \\
\text { dimethoxybenzene (Br- } \\
\text { DMB) }\end{array}$ & 8.3 & 2.08 & \\
\hline ketone dimer $\mathbf{S 3}$ & 9.45 & 1.21 & \\
\hline alkene 4 & 9.98 & 1.27 & \\
\hline bromide 2 & 10.95 & 1.40 & \\
\hline beta vinyl bromide $\mathbf{S} 4$ & 11.65 & 1.49 & \\
\hline Gem-dibromide $\mathbf{S 5}$ & 12.15 & 1.55 & \\
\hline
\end{tabular}




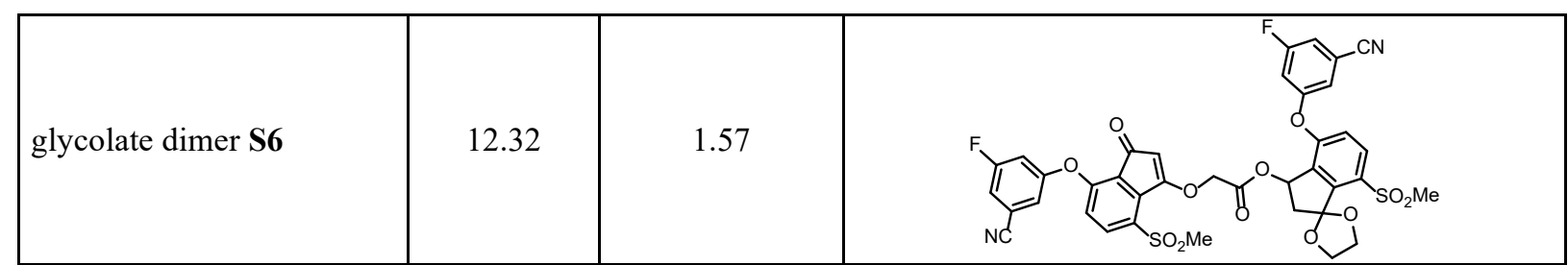

a. all RRT values are relative to final product compound $\mathbf{1}(\mathrm{RT}=7.83)$

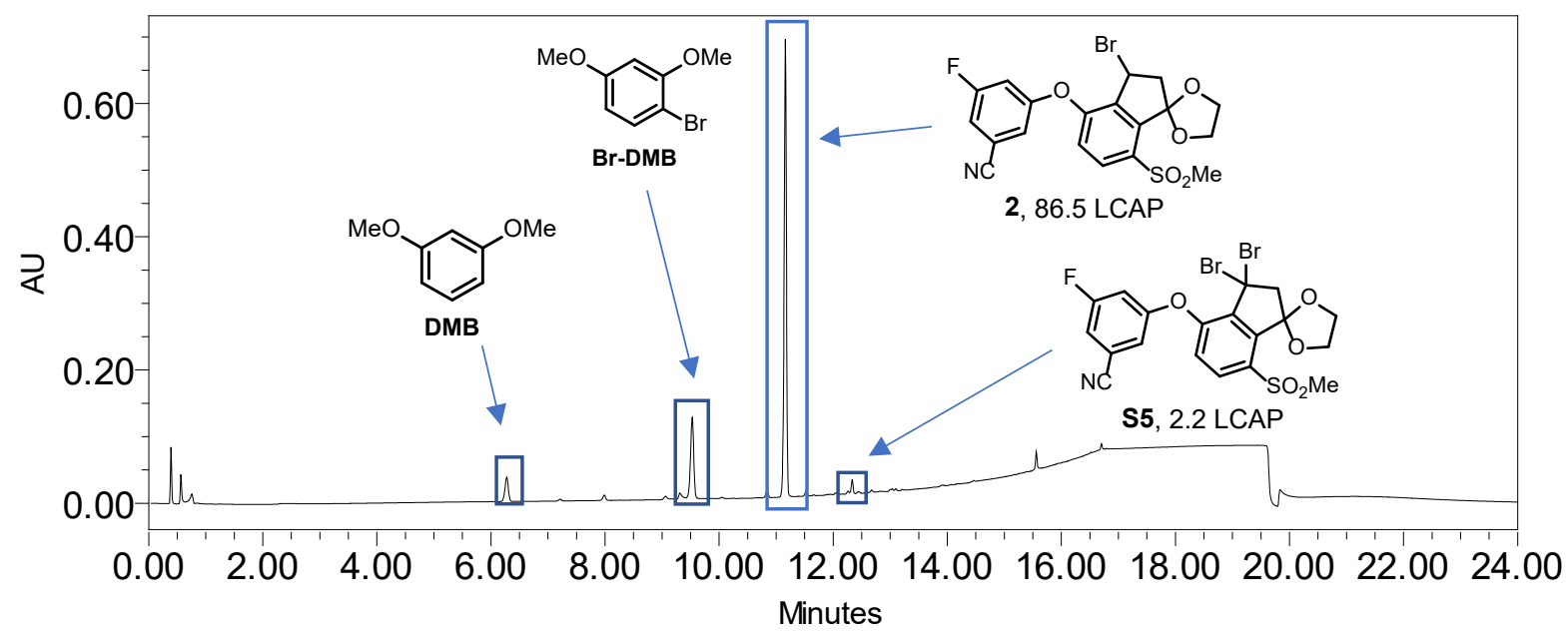

Figure S9. HPLC trace of the quenched solution of bromide 2.

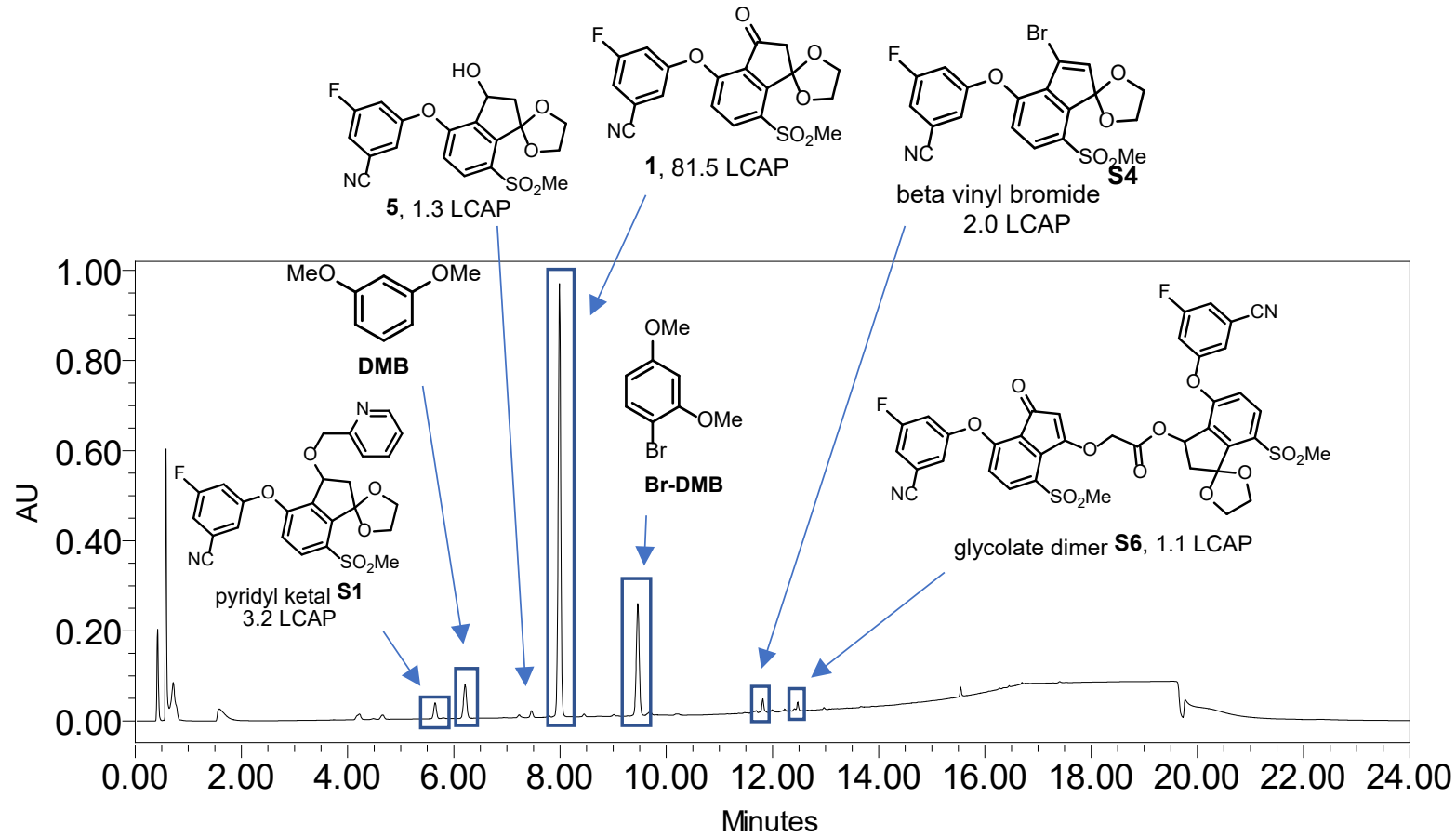

Figure S10. HPLC trace of the oxidation end-of-reaction (EOR) solution. 


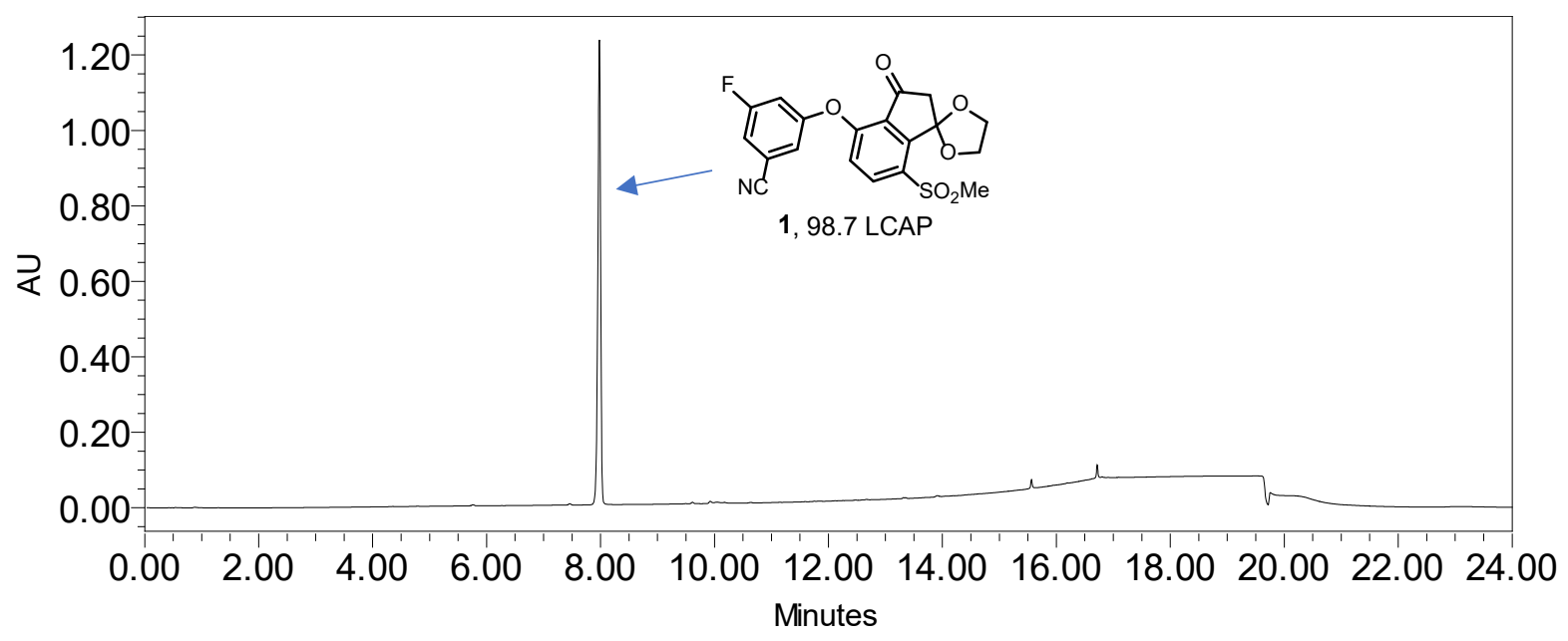

Figure S11. HPLC trace of isolated ketone 1.

\section{NMR data and spectra}

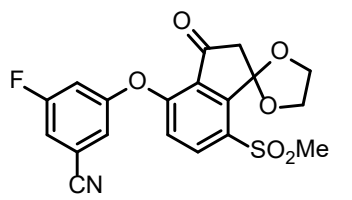

3-fluoro-5-((7-(methylsulfonyl)-3-oxo-2,3-dihydrospiro[indene-1,2'[1,3]dioxolan]-4-yl)oxy)benzonitrile (1). ${ }^{1} \mathrm{H} \mathrm{NMR}\left(500 \mathrm{MHz}, \mathrm{CDCl}_{3}\right): \delta$ (ppm) $8.38(\mathrm{~d}, J=8.6 \mathrm{~Hz}, 1 \mathrm{H}), 7.24(\mathrm{ddd}, J=7.6,2.3,1.3 \mathrm{~Hz}, 1 \mathrm{H}), 7.15$ (dd, $J=2.1,1.0 \mathrm{~Hz}, 1 \mathrm{H}), 7.10(\mathrm{~d}, J=8.6 \mathrm{~Hz}, 1 \mathrm{H}), 7.07$ (dt, $J=9.0,2.3 \mathrm{~Hz}, 1 \mathrm{H}), 4.51-4.41$ (m, 2H), $4.18-4.08(\mathrm{~m}, 2 \mathrm{H}), 3.27(\mathrm{~s}, 3 \mathrm{H}), 2.94(\mathrm{~s}, 2 \mathrm{H}) .{ }^{13} \mathrm{C} \mathrm{NMR}\left(126 \mathrm{MHz}, \mathrm{CDCl}_{3}\right): \delta(\mathrm{ppm}) 195.58$, $163.25(\mathrm{~d}, J=253.1 \mathrm{~Hz}), 156.93$ (d, $J=11.1 \mathrm{~Hz}), 156.27,151.48,139.81,134.66,129.49,120.15$, $118.95(\mathrm{~d}, J=3.7 \mathrm{~Hz}), 116.73(\mathrm{~d}, J=3.6 \mathrm{~Hz}), 116.06(\mathrm{~d}, J=24.8 \mathrm{~Hz}), 115.12(\mathrm{~d}, J=11.4 \mathrm{~Hz})$, $112.61(\mathrm{~d}, J=24.4 \mathrm{~Hz}), 109.79,66.07,50.28,45.14 .{ }^{19} \mathrm{~F}$ NMR $\left(471 \mathrm{MHz}, \mathrm{CDCl}_{3}\right): \delta(\mathrm{ppm})$ 105.62. HRMS: $\mathrm{m} / \mathrm{z}$ calculated for $\mathrm{C}_{19} \mathrm{H}_{14} \mathrm{O}_{6} \mathrm{NFSH}:[\mathrm{M}+\mathrm{H}]^{+}, 404.0604$, found: $404.0603[\mathrm{M}+\mathrm{H}]^{+}$.

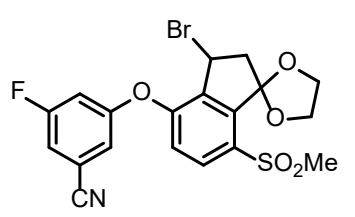

3-((3-bromo-7-(methylsulfonyl)-2,3-dihydrospiro[indene-1,2'[1,3]dioxolan]-4-yl)oxy)-5-fluorobenzonitrile (2). ${ }^{1} \mathrm{H}$ NMR $(500 \mathrm{MHz}$, $\left.\mathrm{CDCl}_{3}\right): \delta(\mathrm{ppm}) 8.11(\mathrm{~d}, J=8.6 \mathrm{~Hz}, 1 \mathrm{H}), 7.23(\mathrm{ddd}, J=7.6,2.3,1.3 \mathrm{~Hz}$, 1H), $7.22-7.19(\mathrm{~m}, 1 \mathrm{H}), 7.09(\mathrm{dt}, J=9.1,2.3 \mathrm{~Hz}, 1 \mathrm{H}), 6.97(\mathrm{~d}, J=8.6 \mathrm{~Hz}$,

1H), 5.44 (dd, $J=7.0,1.9 \mathrm{~Hz}, 1 \mathrm{H}), 4.49-4.36(\mathrm{~m}, 2 \mathrm{H}), 4.18-4.07$ (m, 2H), 3.24 (s, 3H), 2.86 $(\mathrm{dd}, J=14.8,7.0 \mathrm{~Hz}, 1 \mathrm{H}), 2.77(\mathrm{dd}, J=14.8,1.9 \mathrm{~Hz}, 1 \mathrm{H}) .{ }^{13} \mathrm{C} \mathrm{NMR}\left(126 \mathrm{MHz}, \mathrm{CDCl}_{3}\right): \delta(\mathrm{ppm})$ $163.24(\mathrm{~d}, J=253.0 \mathrm{~Hz}), 157.02(\mathrm{~d}, J=11.1 \mathrm{~Hz}), 156.38,142.76,137.00,134.78,133.71,119.22$ 
(d, $J=3.7 \mathrm{~Hz}), 118.87,116.74(\mathrm{~d}, J=3.6 \mathrm{~Hz}), 116.23,115.88(\mathrm{~d}, J=24.8 \mathrm{~Hz}), 115.09$ (d, $J=11.4$ $\mathrm{Hz}), 112.65$ (d, $J=24.3 \mathrm{~Hz}), 66.00,65.65,48.55,45.17,40.15 .{ }^{19} \mathrm{~F}$ NMR (471 MHz, $\left.\mathrm{CDCl}_{3}\right): \delta$ (ppm) -105.66. HRMS: m/z calculated for $\mathrm{C}_{19} \mathrm{H}_{15} \mathrm{O}_{5} \mathrm{BrNFSH}$ : [M+H] ${ }^{+}$, 467.9916, found: 467.9909 $[\mathrm{M}+\mathrm{H}]^{+}$.

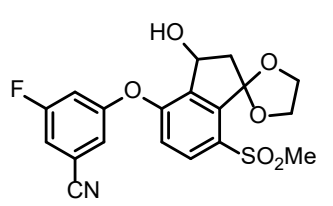

3-fluoro-5-((3-hydroxy-7-(methylsulfonyl)-2,3-dihydrospiro[indene1,2'-[1,3]dioxolan]-4-yl)oxy)benzonitrile (5). ${ }^{1} \mathrm{H}$ NMR $\left(500 \mathrm{MHz}, \mathrm{CDCl}_{3}\right)$ : $\delta(\mathrm{ppm}) 8.08(\mathrm{~d}, J=8.6 \mathrm{~Hz}, 1 \mathrm{H}), 7.21$ (ddd, $J=7.6,2.2,1.3 \mathrm{~Hz}, 1 \mathrm{H}), 7.19-$ $7.16(\mathrm{~m}, 1 \mathrm{H}), 7.07(\mathrm{dt}, J=9.1,2.3 \mathrm{~Hz}, 1 \mathrm{H}), 6.97(\mathrm{~d}, J=8.6 \mathrm{~Hz}, 1 \mathrm{H}), 5.34(\mathrm{dd}, J=6.6,3.6 \mathrm{~Hz}$, 1H), 4.40 (h, $J=3.6 \mathrm{~Hz}, 2 \mathrm{H}), 4.15-4.07$ (m, 2H), 3.26 (s, 3H), 2.61 (dd, $J=13.6,6.6 \mathrm{~Hz}, 1 \mathrm{H}$ ), $2.39(\mathrm{~s}, 1 \mathrm{H}), 2.28(\mathrm{dd}, J=13.6,3.6 \mathrm{~Hz}, 1 \mathrm{H}) .{ }^{13} \mathrm{C} \mathrm{NMR}\left(126 \mathrm{MHz}, \mathrm{CDCl}_{3}\right): \delta(\mathrm{ppm}) 163.25(\mathrm{~d}, J$ $=252.9 \mathrm{~Hz}), 157.36(\mathrm{~d}, J=11.1 \mathrm{~Hz}), 156.90,142.90,138.38,134.18,133.56,119.07$ (d, $J=3.7$ $\mathrm{Hz}), 118.91,116.77$ (d, $J=3.6 \mathrm{~Hz}), 115.69$ (d, $J=24.8 \mathrm{~Hz}), 115.54,115.06$ (d, $J=11.4 \mathrm{~Hz})$, $112.51(\mathrm{~d}, J=24.4 \mathrm{~Hz}), 68.89,65.96,65.84,47.11,45.02 .{ }^{19} \mathrm{~F} \mathrm{NMR}\left(471 \mathrm{MHz}, \mathrm{CDCl}_{3}\right): \delta(\mathrm{ppm})$ -105.72. HRMS: $\mathrm{m} / \mathrm{z}$ calculated for $\mathrm{C}_{19} \mathrm{H}_{16} \mathrm{O}_{6} \mathrm{NFSNa}:[\mathrm{M}+\mathrm{Na}]^{+}, 428.0580$, found: 428.0584 $[\mathrm{M}+\mathrm{Na}]^{+}$.

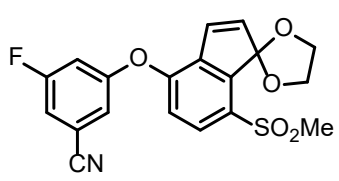

3-fluoro-5-((7-(methylsulfonyl)spiro[indene-1,2'-[1,3]dioxolan]-4yl)oxy)benzonitrile (4). ${ }^{1} \mathrm{H}$ NMR (500 MHz, $\left.\mathrm{CDCl}_{3}\right): \delta$ (ppm) 7.84 (d, $J=$ $8.7 \mathrm{~Hz}, 1 \mathrm{H}), 7.16$ (ddd, $J=7.6,2.0,1.2 \mathrm{~Hz}, 1 \mathrm{H}), 7.10-7.07$ (m, 1H), 7.01 (d, $J=8.7 \mathrm{~Hz}, 1 \mathrm{H}), 6.97(\mathrm{dt}, J=9.3,2.3 \mathrm{~Hz}, 1 \mathrm{H}), 6.56(\mathrm{~d}, J=6.0 \mathrm{~Hz}, 1 \mathrm{H}), 6.27(\mathrm{~d}, J=6.0 \mathrm{~Hz}$, $1 \mathrm{H}), 4.55-4.43(\mathrm{~m}, 2 \mathrm{H}), 4.21-4.12(\mathrm{~m}, 2 \mathrm{H}), 3.18(\mathrm{~s}, 3 \mathrm{H}) .{ }^{13} \mathrm{C} \mathrm{NMR}\left(126 \mathrm{MHz}, \mathrm{CDCl}_{3}\right): \delta(\mathrm{ppm})$ 163.28 (d, $J=252.4 \mathrm{~Hz}), 158.20$ (d, $J=11.0 \mathrm{~Hz}), 151.47,143.53,136.82,135.73,134.53,130.49$, 125.63, 121.61, 117.69 (d, $J=3.6 \mathrm{~Hz}), 116.86$ (d, $J=3.6 \mathrm{~Hz}), 115.72,114.98$ (d, $J=11.5 \mathrm{~Hz})$, $114.87(\mathrm{~d}, J=24.9 \mathrm{~Hz}), 111.05(\mathrm{~d}, J=24.6 \mathrm{~Hz}), 66.05,45.53 .{ }^{19} \mathrm{~F}$ NMR $\left(471 \mathrm{MHz}, \mathrm{CDCl}_{3}\right): \delta$ (ppm) -105.94. HRMS: m/z calculated for $\mathrm{C}_{19} \mathrm{H}_{14} \mathrm{O}_{5} \mathrm{NFSH}:[\mathrm{M}+\mathrm{H}]^{+}, 388.0655$, found: 388.0649 $[\mathrm{M}+\mathrm{H}]^{+}$. 

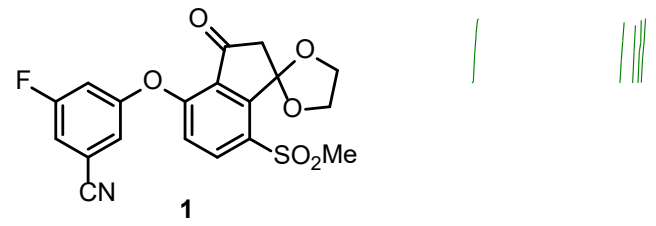

${ }^{1} \mathrm{H}$ NMR $\left(500 \mathrm{MHz}, \mathrm{CDCl}_{3}\right)$
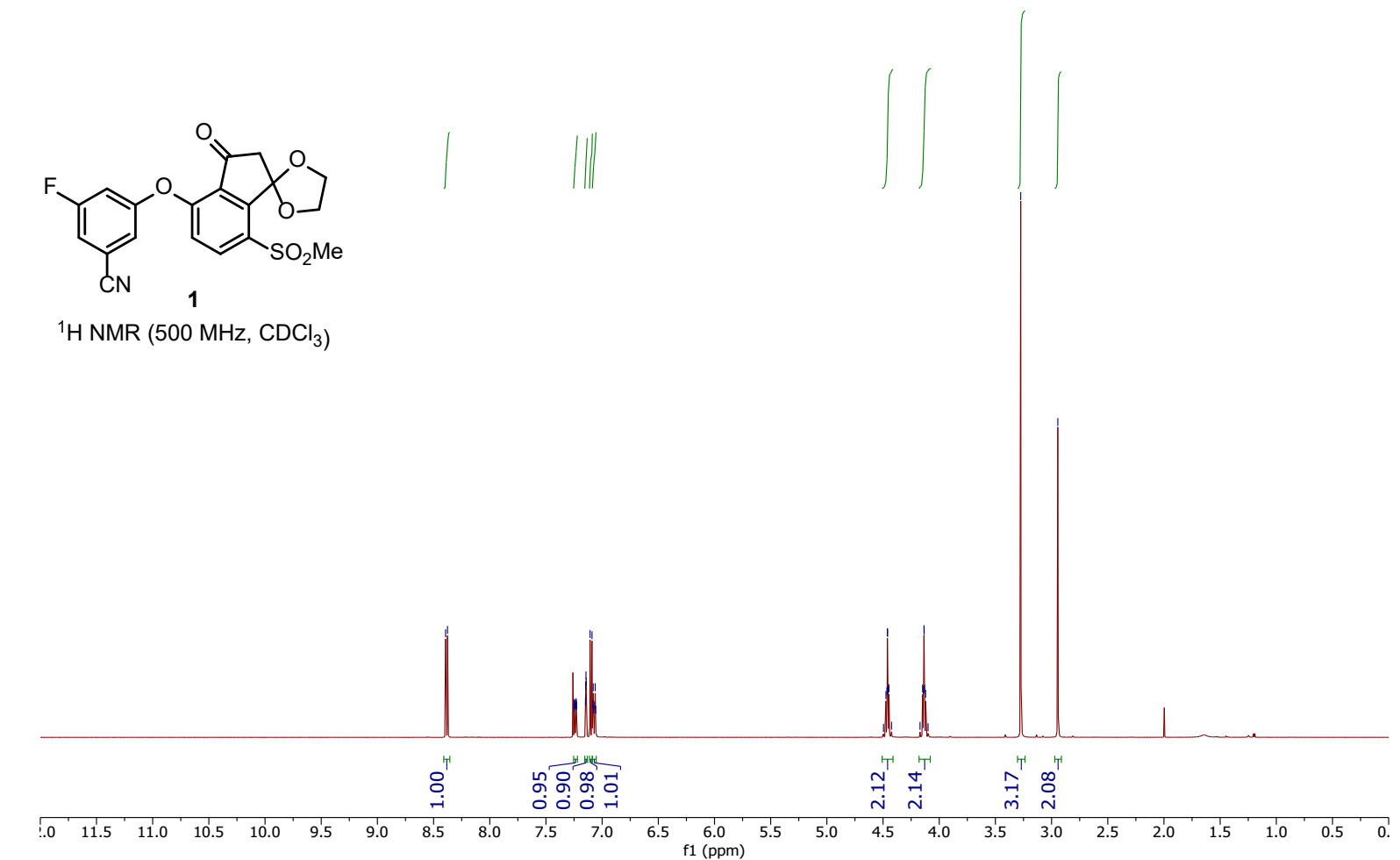

PT3861.45.fid

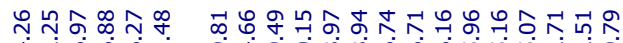

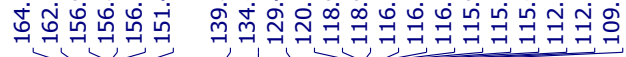

$\hat{0}$
$\dot{0}$

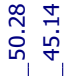

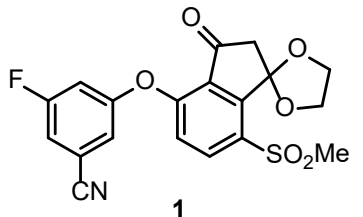

${ }^{13} \mathrm{C}$ NMR $\left(126 \mathrm{MHz}, \mathrm{CDCl}_{3}\right)$

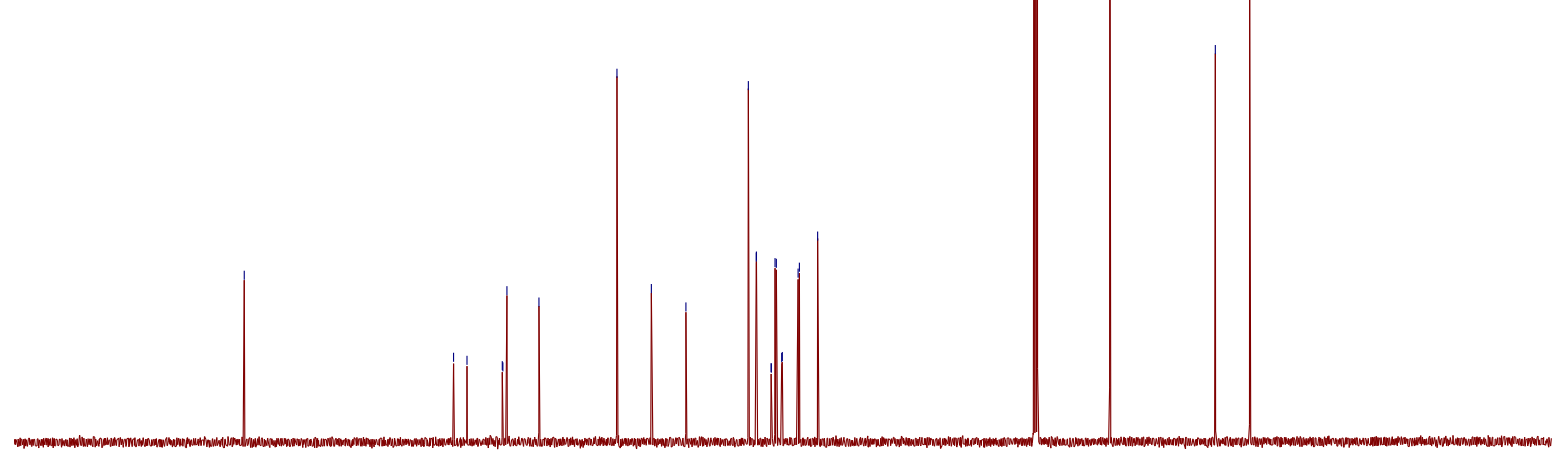

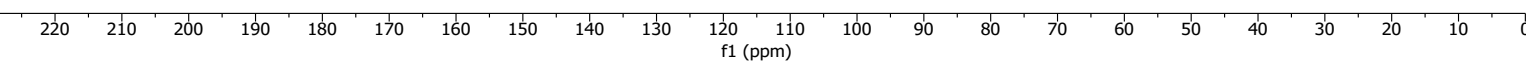




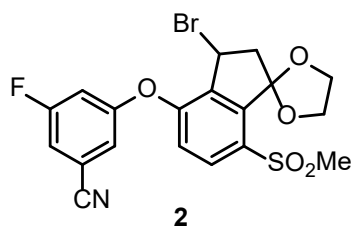

${ }^{1} \mathrm{H}$ NMR $\left(500 \mathrm{MHz}, \mathrm{CDCl}_{3}\right)$
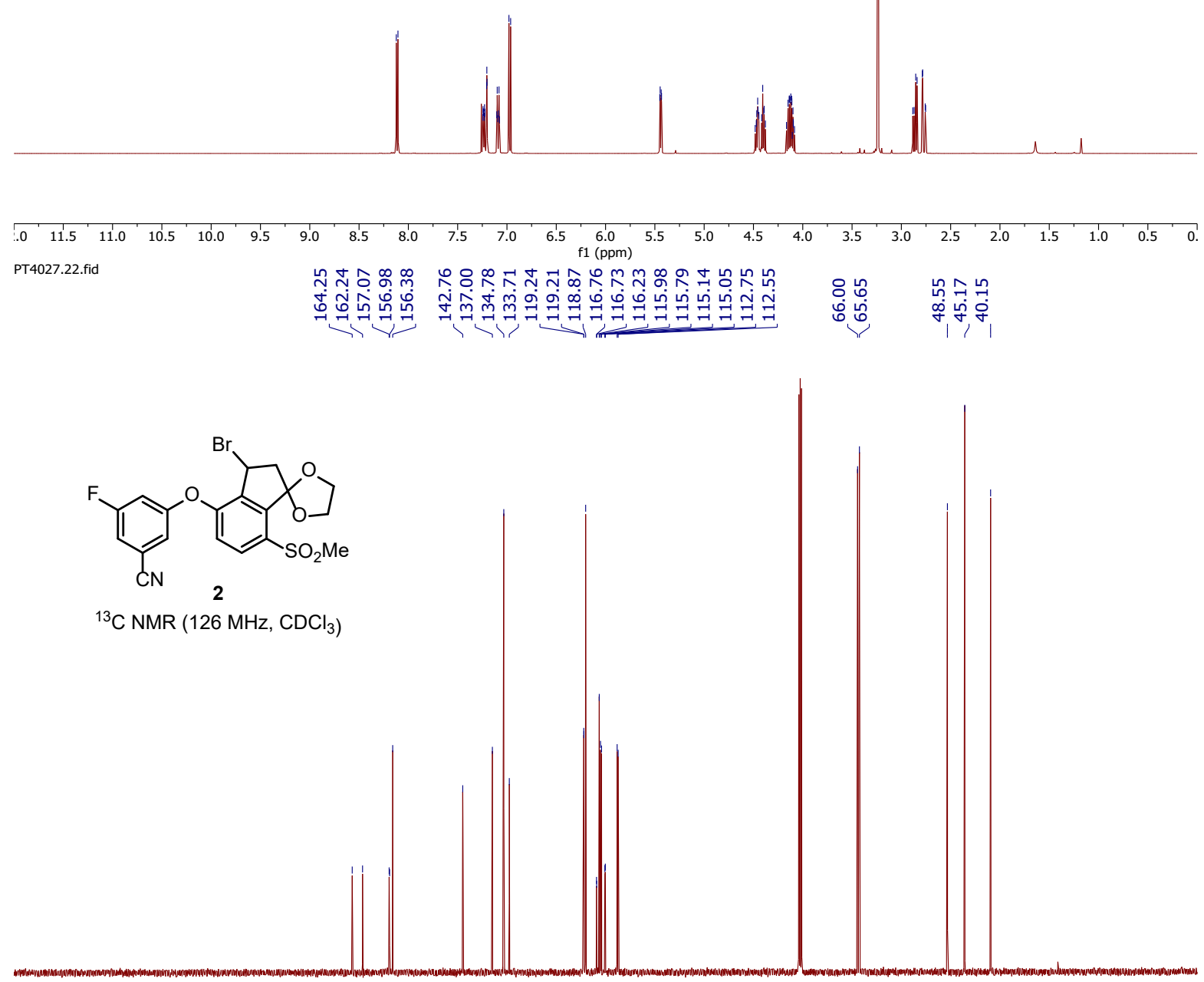

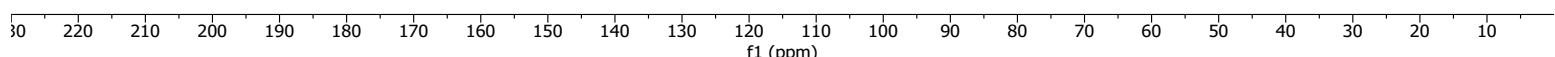



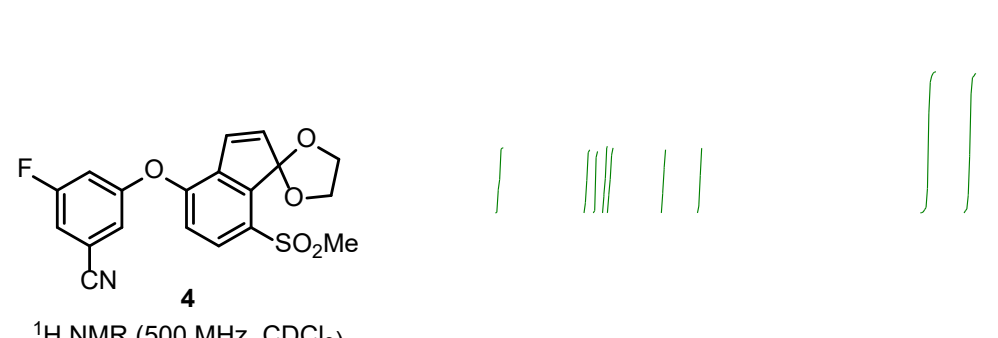

${ }^{1} \mathrm{H} \mathrm{NMR}\left(500 \mathrm{MHz}, \mathrm{CDCl}_{3}\right)$
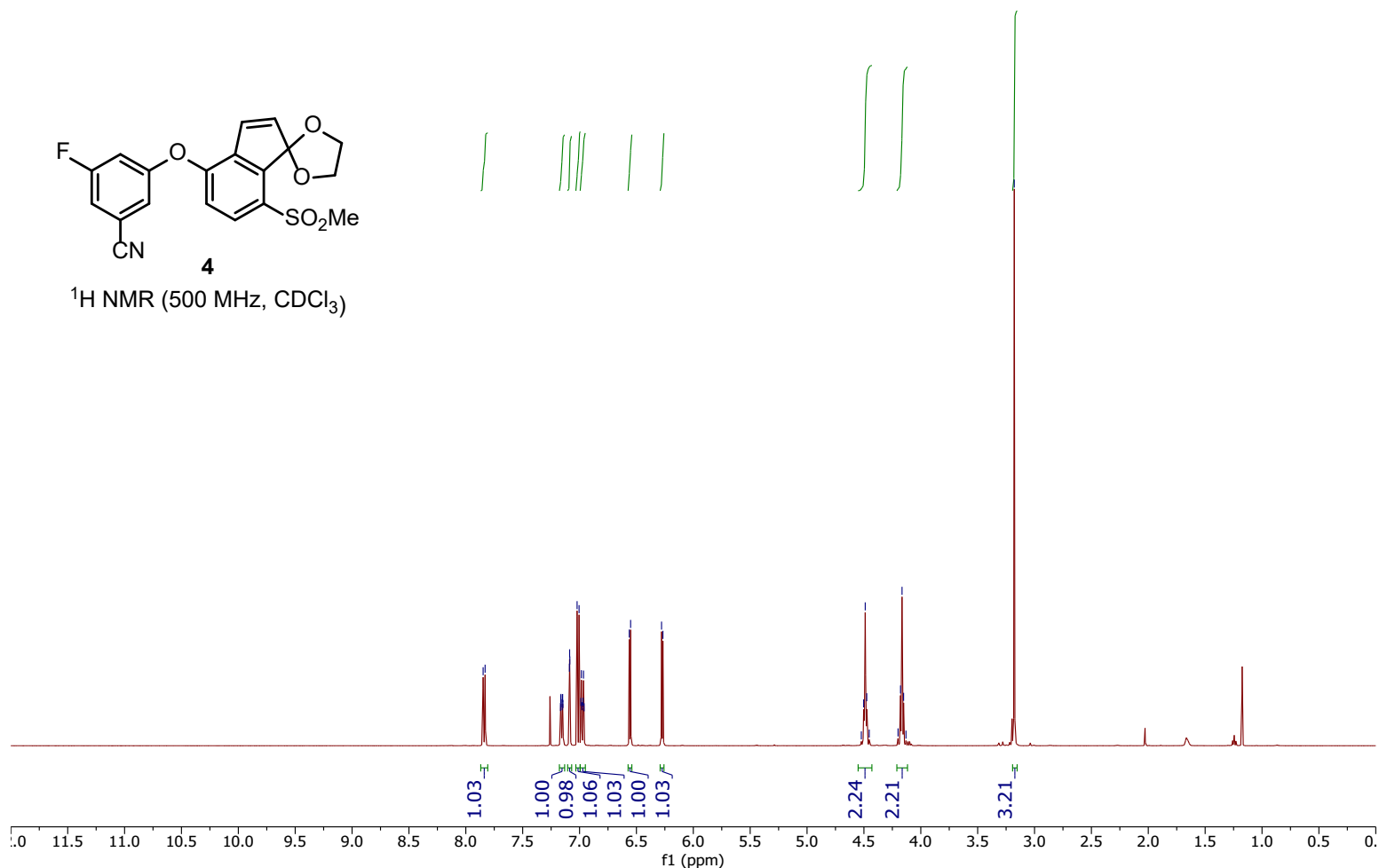

ene ketal.55.fid

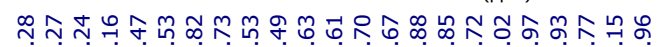

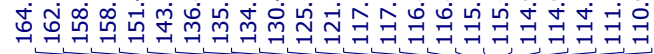

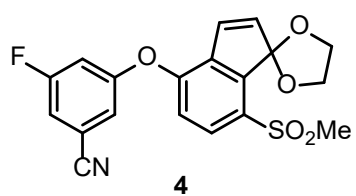

${ }^{13} \mathrm{C}$ NMR $\left(126 \mathrm{MHz}, \mathrm{CDCl}_{3}\right)$

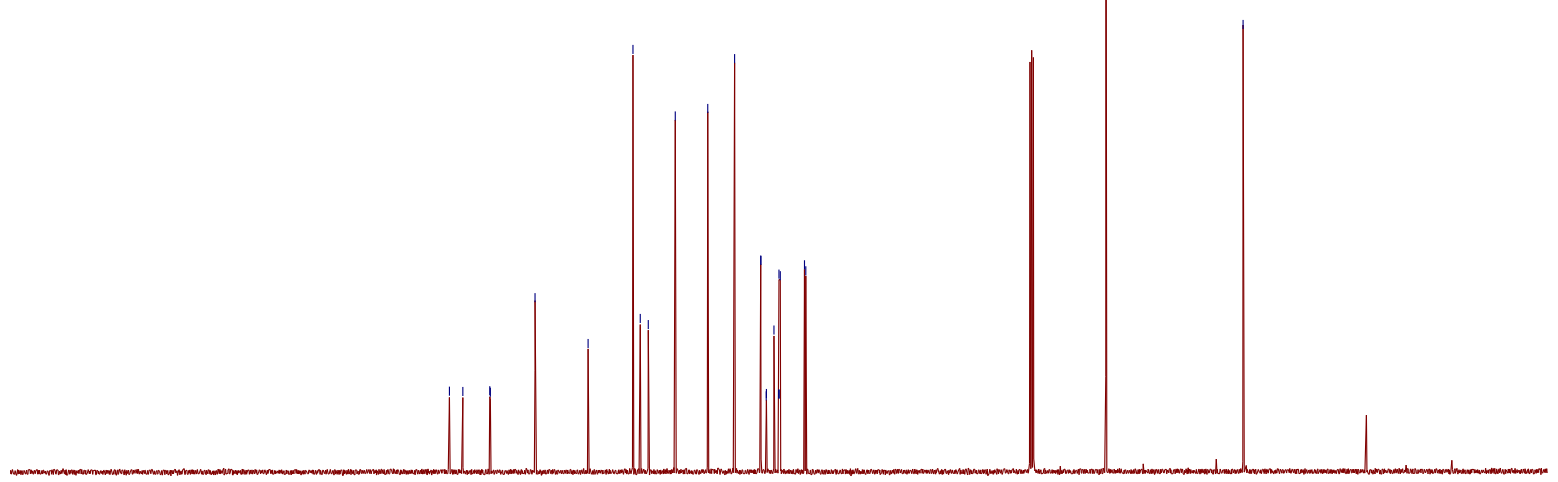

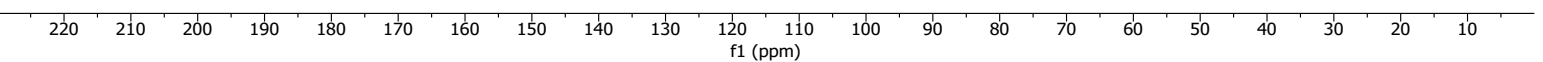



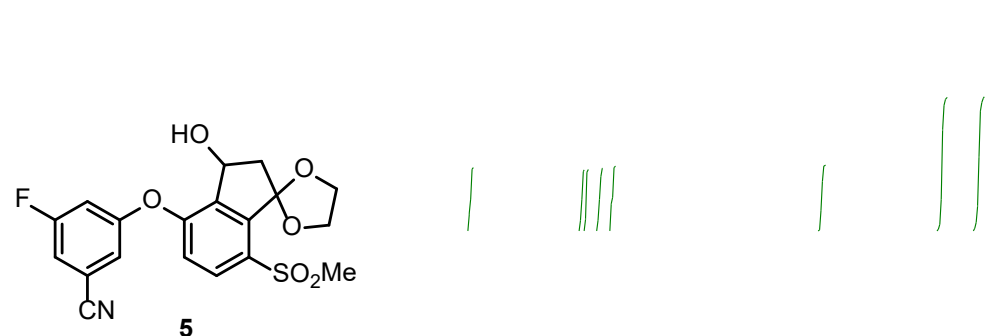

${ }^{1} \mathrm{H} \mathrm{NMR}\left(500 \mathrm{MHz}, \mathrm{CDCl}_{3}\right)$
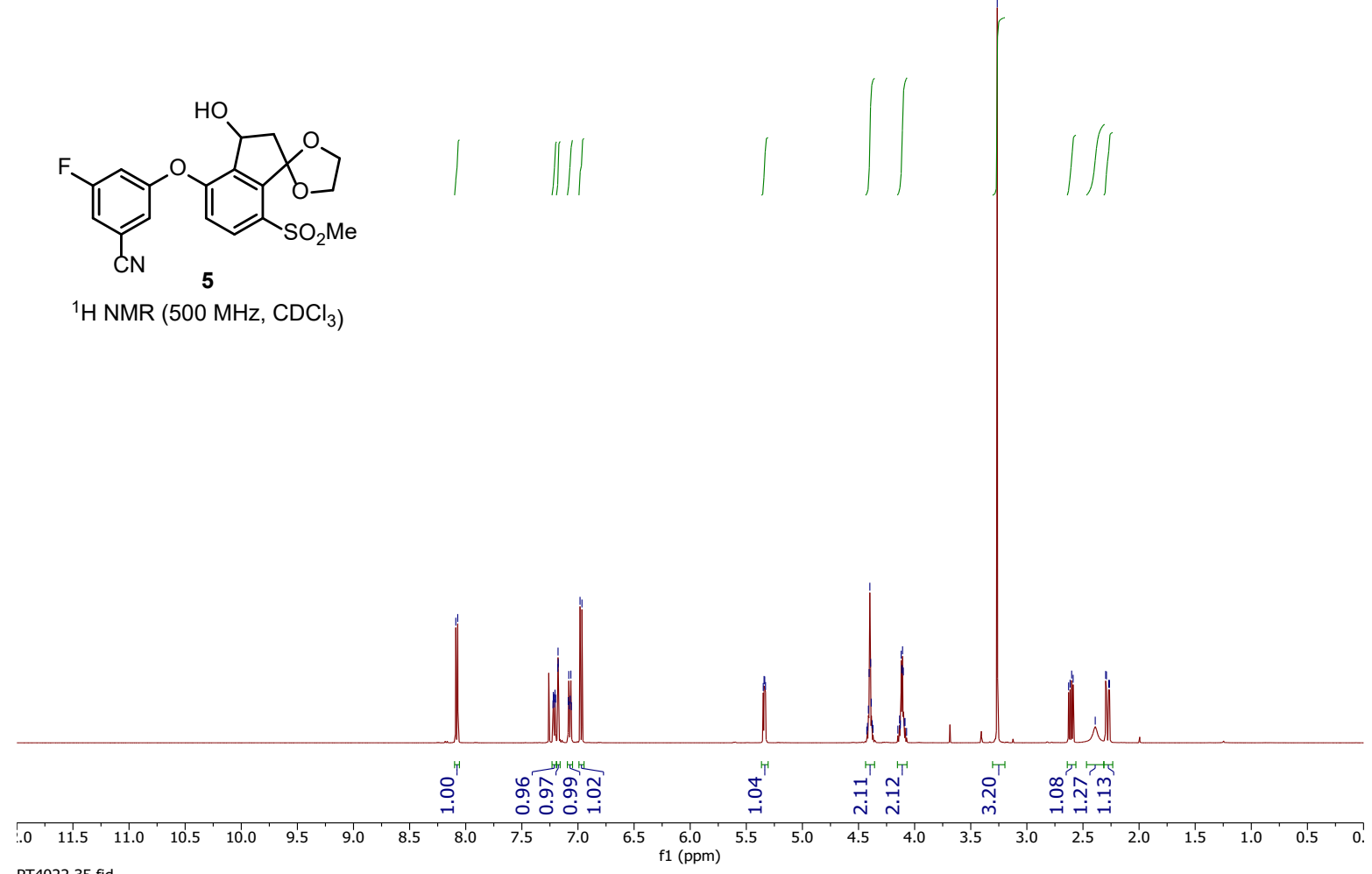
PT4022.35.fid

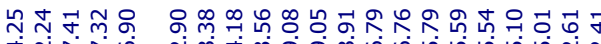

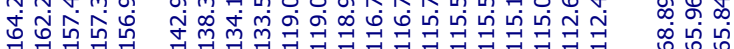

fं

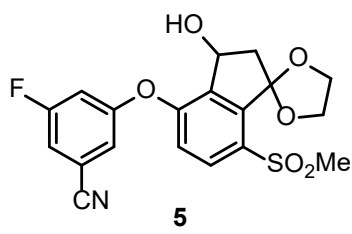

${ }^{13} \mathrm{C} \mathrm{NMR}\left(126 \mathrm{MHz}, \mathrm{CDCl}_{3}\right)$

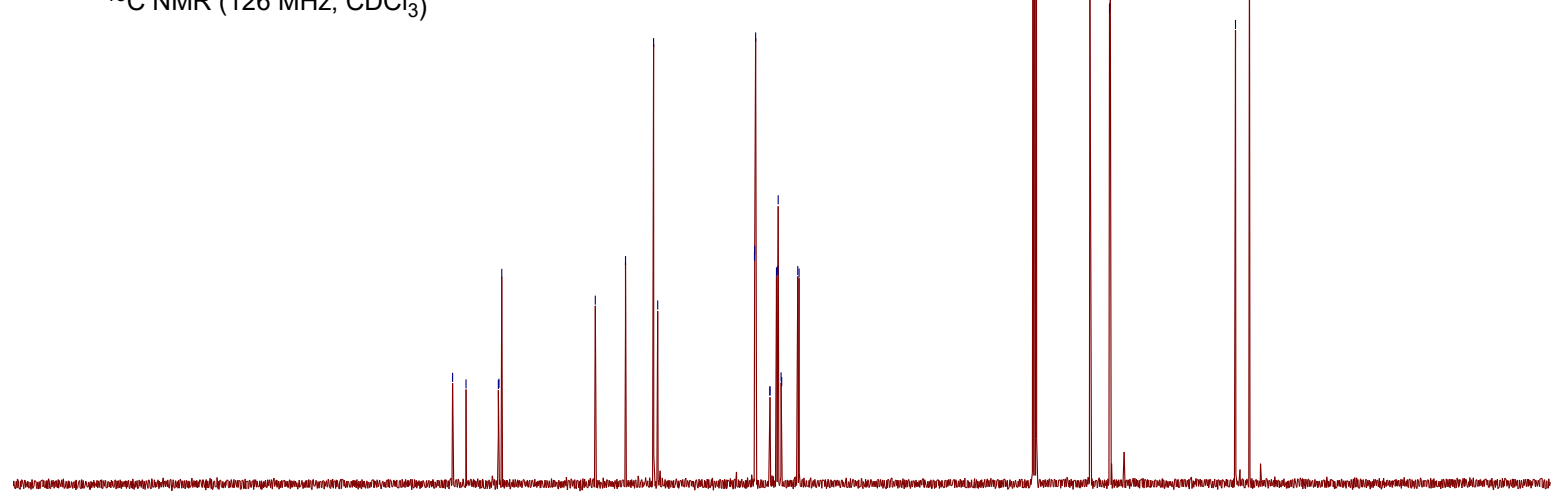

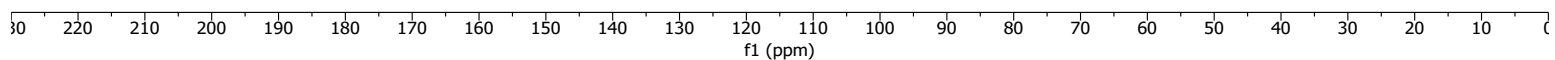




\section{References}

${ }^{1}$ (a) Gottlieb, H. E.; Kotlyar, V.; Nudelman, A. NMR Chemical Shifts of Common Laboratory Solvents as Trace Impurities. J. Org. Chem. 1997, 62, 7512-7515. (b) Fulmer, G. R.; Miller, A. J. M. Sherden, N. H.; Gottlieb, H. E.; Nudelman, A.; Stoltz, B. M. Bercaw, J. E.; Goldberg, K. I. NMR Chemical Shifts of Trace Impurities: Common Laboratory Solvents, Organics, and Gases in Deuterated Solvents Relevant to the Organometallic Chemist. Organometallics 2010, 29, 2176-2179.

${ }^{2}$ Reagent charges, yields, and losses are based on ketal $\mathbf{3}$ in this scale-up. 